\title{
Hititlerde Yerleşim Yeri-Kutsal Dağ İlişkisi Üzerine Bir Mesafe Önerisi ${ }^{*}$
}

\author{
Prof. Dr. Hasan Bahar \\ Selçuk Üniversitesi \\ Edebiyat Fakültesi \\ Tarih Bölümü \\ hbahar@selcuk.edu.tr
}

\author{
Dr. Murat Turgut \\ Selçuk Üniversitesi \\ Edebiyat Fakültesi \\ Tarih Bölümü \\ mturgut@selcuk.edu.tr
}

\author{
Okt. Bora Küçük \\ Selçuk Üniversitesi YADAM \\ Almanca Bölümü \\ boraclein@selcuk.edu.tr
}

Öz

Eskiçağ Tarihindeki birçok toplum gibi Hititler de dağların kutsal mekan olduklarını düşünmüşlerdir. $\mathrm{Bu}$ düşüncelerinin altında dağları tanrı olarak ve tanrıların yaşadıkları mekan olarak görmeleri vardır. Hititler bu düşünceleri sayesinde bazı ritüellerini dağlarda gerçekleştirmişlerdir. Hititler dini hayatlarında kullanmak için yerleşim yerlerinin yakınlarındaki bazı dağların kutsal olduklarını düşünmüşlerdir. Bu dağları kentleri ile özdeşleştirmişlerdir. Boğazkale - Yazılıkaya, Ortaköy - Ağılönü, Alacahöyük - Kalehisar Tepesi, Kuşaklı - Karatonus/Kulmaç Dağı, Oymaağaç - Adatepe, Çadır höyük - Çaltepe, Hatıp höyük - Hatıp kayalıkları, Maltepe Höyük - Arısama Dağı bunların en göze çarpanları olmuştur. Hitit yazılı belgelerinde, kentlerin dışında kalan açık hava kutsal mekanlarının nasıl belirlendiği konusunda açıklayıcı bilgiler bulunmamaktadır. Bizim düşüncemize göre ise kentlerin yakınlarında bulunan kutsal dağlar, birkaç saatlik yürüme mesafesinde $(5 \mathrm{~km}$.) yer almaktadır. Biz bu çalışmamızda, Hitit yönetici veya din adamlarının, kentlerinin kutsal dağlarını belirlerken, belirli bir mesafeye kadar olan yerleri seçtiklerini önereceğiz.

Anahtar Kelimeler: Dağ kültü, dağ inançları, kutsal mekan, Hitit kentleri, Hitit şehirleri.

\footnotetext{
* Bu makale, Selçuk Üniversitesi BAP Koordinatörlüğü tarafından desteklenen ve Prof. Dr. Hasan Bahar danışmanlığında tamamlanan Hitit Dini Düşüncesinde Kutsal Mekanlar (M. Ö. 1650 - M. Ö. 1200) başlıklı Yüksek Lisans tezinden üretilmiştir. 


\title{
A Perspective of Distance on the Relation Between Settlement - Sacred Mountain in Hittites
}

\begin{abstract}
Hittites thought that mountains were sacred places just as other societies in the ancient history. This was due to the idea that a mountain was viewed as a God and as an ermitage. Therefore, Hittites made some of their rituals on the mountains. Hittites thought some mountains, near their cities, were sacred mountains to be used in their religious lives. They consubstantiated these mountains with cities. The most notable ones are Boğazkale Yazılıkaya, Ortaköy - Ağılönü, Alacahöyük - Kalehisar Tepesi, Kuşaklı - Karatonus/Kulmaç Dağı, Oymaağaç - Adatepe, Çadır höyük - Çaltepe, Hatıp höyük - Hatıp kayalığı, Maltepe Höyük - Arısama Dağı. There is no explanatory information in the Hittites cuneiform texts related with how open - air sacred spaces were chosen. We think that sacred mountains near the Hittite settlements were located within a few hours walking distance. In this paper, we will suggest that when Hitttie administrators or clergymen determined the sacred mountains of cities, they prefered to limit the distance within $5 \mathrm{~km}$.
\end{abstract}

Keywords: Mountain cult, mountain beliefs, sacred space, Hittite cities, Hittite towns. 


\section{GİRIŞ}

İnsanlar kendi güçlerinin yetmediği olaylar karşısında doğa üstü güçlerin yani tanrıların var olduklarını düşünmüşlerdir. Tanrıların varlıklarını belirledikten sonra, onların yaşadıkları yerlerin de olması gerektiğini kabul etmişlerdir. Bu doğrultuda tanrısal güçlerin, kendileri için birçok anlama sahip olan göklerde ${ }^{1}$ var olduklarını hayal etmişlerdir. Dağları da göklere yakınlığından dolayı tanrısal varlıkların yaşadıkları veya dünya ile iletişime geçtikleri mekanlar olarak görmüşlerdir.

Dağ kültleri incelendiği zaman, dağlar, dünyanın merkezi, dinsel vahiy yerleri, tanrısal varlıkların oturdukları veya yaşadıkları yerler ve tanrının kendisi olarak düşünülmüştür (García Trabazo 2009: 69). Dağların yüceliği ve güneşin dağların ardında batması gibi, insanlar için hayranlık uyandırabilecek durumlar da insanların dağlar hakkındaki düşüncelerini etkilemiş olabilir (Baydur 1994: 1). Dağların kutsallığı ve dağ kültü, özellikle Eski Yakındoğu dinlerinde ve Anadolu'da yaygın bir fenomen olmuştur (Lombardi 1997: 85). Bazı Mezopotamya eserlerinde tanrı, bir güneş gibi, iki dağ arasından gelmektedir. Mezopotamya toplumları tarafından yapılmış olan zigguratlar, kozmik dağı simgeleyen yapay dağlar olarak değerlendirilmiştir. Ayrıca dağlar yine Mezopotamyalılar tarafından "öte dünyanın eşiği" olarak da görülmüştür. Mezopotamya toplumlarının dini düşüncelerine göre ruhlar, ölüler diyarına dağları geçerek gitmişlerdir. Assur dilinde ölmek için kullanılan terim "dağlara tutunmak/yapışmak" olmuştur. Benzer şekilde Mısır'da ölmek için kullanılan terim yine "dağlara tutunmalyapışma" anlamına gelen "myny" terimi kullanılmıştır (Eliade 2004: 26-28; Eliade 2009: 116, 362, 363).

Dağlar, çok tanrılı dinler haricinde, tek tanrılı dinlerde de kutsal bir mekan olmuştur. Eski Ahitte Tanrı Musa'ya "Gerçekten ben seninle olacă̆ım ve benim, seni gönderdiğime, senin için şu işaret olacak: sen kavmi Mısır'dan çıkardığın zaman, bu dă̆ üzerinde tanrıya ibadet edeceksiniz." (Çıkış 3.12) şeklinde seslenmektedir. Bu bilgiden hareketle dağlarda ibadet edilebildiğini düşünebiliriz. Ayrıca Kuran'ın ilk vahiyleri de Nur dağında gelmiştir. Bu bilgiler dağların kutsiyetini göstermesi açısından önemlidir.

Dağ tanrıları veya tasvirleri, erken dönemlerde dağ şeklinde gösterilmiştir. Bu tasvirler daha sonra theriomorphic (hayvan biçimli) biçimde olmuştur ${ }^{2}$. Dağ tanrıları, MÖ III. Binyıldan itibaren ise üst tarafı antropomorphic (insan biçimli); alt tarafı ise kılçıklı kabarık bir şekilde gösterilmişlerdir. Dağların sahip olduğu kayalar ve ağaçlardan dolayı bu şekilde tasvir edildikleri düşünülmektedir (Beckman 2013: 155; García Trabazo 2009: 81). Ayrıca Dağ Tanrılarının gürz ve topuz ile sembolize edildiği de bilinmektedir.

Birçok görsel tasvirde Fırtına Tanrısı, dağ tanrılarının üzerinde tasvir edilmiştir. Bu durum García Trabazo tarafından, mitolojik mücadelelerdeki Fırtına Tanrısının dağ tanrıları karşısında kazandığı zafere bağlanmaktadır (García Trabazo 2009: 77).

\section{HİTİT DİNINDE DAĞ KÜLTÜ}

MÖ II. binyılda Anadolu'da yaşamış olan Hititler de Mezopotamya ve Mısır toplumları gibi dağların kutsal olduklarını düşünmüşlerdir. Özellikle Mezopotamya toplumlarındaki kutsal dağ inancı Hurri ve Kizzuwatna toplumlarının etkileri ile Hitit dinine geçmiştir.

\footnotetext{
${ }^{1}$ Gökyüzünün konumuz ile ilişkili dinsel anlamı için bk. Eliade 2009: 61.

2 Dağ tanrılarının hayvan biçimli tasvirlerinin genellikle boğa hayvanı şeklinde olduğu düşünülmektedir. Çevik 2007: 176.
} 
Hitit toplumu için dağlar birçok anlama sahip olmuştur. Bunların en başında, insanlar için yaşamı düzenleyen tanrıların, gökyüzünde veya dağlarda bulunduğu/yaşadığı düşüncesi gelmektedir. Bryce, Hititlerin ritüellerinde tanrıyı çağırdıkları zaman tapınağın veya ritüel alanının yakınlarında bulunan en yakın dağa geldiğini belirtmektedir ${ }^{3}$. Bu bilgiden tanrıların gökyüzünde yaşadıklarını ve dünya ile iletişime geçecekleri zaman ilk ulaşım noktalarının dağlar olduğunu düşünebiliriz.

Dağlar Hititler için sadece tanrıların yaşadığı bir yer olmamıştır. KBo 1.8 numaralı metinde III. Hattušili'nin Šuppiuliuma ile ilgili belirttiği "Büyük Babam Šuppiluliuma dăga ulaştığında" (Haas 1994: 216; Ensert 2006: 86) sözlerinden hareketle, ölen Hitit krallarının da tanrılar gibi dağlarda bulunduğunu/yaşadığını söyleyebiliriz.

Hititlerin dağlar haricinde, dağ kültü inançları ile ilgili bağlantılı olarak, işlem görmemiş büyük kayalara da dağ kültü inançlarında yer verdikleri görülebilmektedir. Özellikle Yazılıkaya açık hava tapınağında bulunan bazı kayaların işlem görmemiş olmalarına rağmen kült nesnesi olarak kullanıldığı düşünülmektedir (Schirmer 1982: 19; Darga 1985: 70 - 71).

Hititlerin dini inanç sistemine göre tanrıların yaşadıkları yerler olan dağlar, aynı zamanda birer tanrı olarak da görülmüşlerdir. Hititlere ait birçok dua metninde ${ }^{4}$ kendisine dua yapılan; siyasi antlaşma metinlerinde (Beckman 1996) ise antlaşmaların şahidi olarak yer almışlardır. Ayrıca Hititler tarafından gerçekleştirilen birçok ritüelde de tanrısal dağlara sunu yapıldığı görülmektedir 5 .

Yazılıkaya, Fraktin, Taşçı, Gezbeli, Hanyeri, İmamkulu kabartmalarında, bazı mühürlerde ve yazılı belgelerde dağ tanrılarını görebilmekteyiz. Bu dağlar çivi yazılı belgelerde tanrı işareti olan DINGIR determinitifi ile gösterilmişlerdir. Dağ tanrıları görsel eserlerde genellikle alt kısımları balık pullu şeklinde tasvir edilmişlerdir. Hanyeri kabartmasında ise kutsal olduğu düşünülen dağ, kılıç sembolü ile temsil edilmiştir (Hawkins 2015: 1).

Bazı Hitit kült envanteri metinleri, Fırtına Tanrısı hakkında bilgi verirken, onun iki dağ tanrısı üzerinde durduğundan bahsetmektedir'6. Bu durum, Yazılıkaya A Odası Karşılaşma Sahnesi, B odası IV. Tuthalia kabartması ve İmamkulu kabartmalarında da görüldüğü üzere görsel olarak da doğrulanabilmektedir. Daha önce de belirtildiği üzere García Trabazo, Fırtına Tanrısının, Dağ tanrılarının üzerinde yer almasını, Fırtına Tanrılarının onlara karşı kazandığı zafer ile ilişkilendirmektedir (García Trabazo 2009, 77). Ancak biz, bu fikrin doğrı olabileceğini de düşünmekle birlikte, dağların, tanrıların, özellikle de Fırtına Tanrısının yaşadığı yerler olmasından dolayı, Hitit sanatına bu şekilde yansıdığını düşünmekteyiz.

Hititlerin dini hayatlarında gerçekleştirdikleri ritüellerin veya festival kutlamalarının bir bölümü dağlarda gerçekleştirilmiştir. KUB XXV 23. i 8 numaralı metinde: "İlkbahar geldiği ve şimşekler çakmaya başladığı zaman ... rahipler ... Dă̆ Tanrısı Halwanna'yı dă̆ın tepesine çıkartırlar. Ĕğer bölge düşman kontrolü altındaysa, onlar, onu, dağa (dağdaki) ă̆acın altında duran

\footnotetext{
${ }^{3}$ Bryce 2002: 153 - 155. Ayrıca, Kaybolan tanrı mitosu ve Illuyanka efsanesi gibi mitolojik hikayelerinde de tanrılar gökyüzünde veya dağlarda bulunmakta ve oralardan davet edilmektedir. Hoffner 1990: 12, 15.

${ }_{4}^{4}$ Örneğin CTH 381 numaralı Muwattali'nin Fırtına Tanrısı aracilığıyla tanrılar meclisine yaptı̆̆ı duada, Daha, Šarlaimi, Huwalanuwanda ve Takurga gibi dağlar yer almaktadır. Singer 2002: 87-90.;

${ }^{5}$ CTH 682.3: KBo 12.59 Öy. 1 1: “Kral Tuthaliya'nın düzenli olarak avlandığı [ve] ta[kip] ettiği Šaluwanta dağına bir [erkek keçi]"; McMahon 1991: 133; Ayrıca KUB 9. 17 numaralı metinde de tanrısal Daha Dağı'na bir kez içildiğinden bahsedilmektedir. Mc Mahon 1991: 221.

6 "Fırtına Tanrısı bir erkek heykeldir ve altınla kaplanmıştır. Să̆ elinde asa/mızrak, sol elinde iyilik sembolü taşımakta ve iki dă̆ tanrısı üzerinde durmaktadır." Brandenstein 1943: 6.
} 
huwaši taşına götürürler. Onlar ekmek bölerler ve bira sunarlar ${ }^{7}$." ifadeleri geçmektedir. Bu bilgiler dağların ritüellerde kullanılan bir kutsal mekan olduğunu açık bir şekilde göstermektedir.

Hititler ritüel mekanı olarak dağları seçtikleri gibi damları ${ }^{8}$ da ritüel mekanı olarak seçmişlerdir. Örneğin tanrıça Pirinkir için yapılan ritüelde, tanrıçanın heykeli dama çıkarılmaktadır. Ritüel kutlamalarına damda devam edilerek tanrıçaya çeşitli sunular gerçekleştirilmiştir. Ritüelin sonunda ise tanrıçanın heykeli damdan alınıp tapınağa götürülmüştür (Darga 1985: 126, 127). Bu ritüelden hareketle de bazı ritüellerin tanrılara yakın olabilmek amacıyla damlarda gerçekleştirildiğini düşünebiliriz.

Yazılı belgelerden Hititlerin çok sayıda kutsal dağa sahip olduğunu öğrenmekteyiz. Teşup'un danası olarak bilinen Šarruma Hitit dininde önemli bir dağ olmasının yanı sıra IV. Tuthaliya tarafından kendisine koruyucu tanrı seçilmiştir. Namni ve Hazzi dağları da Fırtına Tanrısının üzerinde durduğu dağ çifti olarak görülmektedir ${ }^{9}$.

Hitit ritüellerinde görülen bazı dağlar sadece dinsel bakımdan önemli olmamışlar aynı zamanda da sembolik öneme de sahip olmuşlardır. Burada belirteceğimiz dağlar Tapala ${ }^{10}$ ve Piškurunuwa ${ }^{11}$ Dağlarıdır.

Tapala Dağı Hitit ritüellerinde, ritüellerin gerçekleştirildiği mekan ${ }^{12}$, kutlanan tanrısal bir dağ ${ }^{13}$ ve bazı ritüellerde hem dağın kendisi hem de dağın koruyucu tanrısı için ${ }^{14}$ sunu yapılan bir dağ olarak görülmektedir. Piškurunuwa Dağı da benzer şekillerde Hitit metinlerinde ritüelin gerçekleştirildiği mekan ${ }^{15}$, kendisine içilen bir tanr1 ${ }^{16}$ olduğu bilinmektedir.

Lombardi'nin önerisinde (Lombardi 1997: 109) özellikle AN.TAH.ŠUMŠAR bayramında kutlanan Tapala ve Piškurunuwa Dağı farklı bölgelerde yer almıştır. Bundan dolayı

\footnotetext{
7 Gurney 1977: 27. Ayrıca Ay tanrısına yapılan bir tarpalli- sunusunda, canlı bir boğa Ay Tanrısının yüksek yerlerine götürülmekte ve orada sunulmaktadır. KUB XXIV 5 + IX 13 Vs. 6-13: “Gece olduğu [zaman] kral önceli Labarna'nın resimlerini alır ve Ay Tanrısı harpa'ya gider. [ ] ve şöyle konuşur: Gör, hangi olaydan dolayı dua etmeye geldiğ̈imi, şimdi beni dinle, Ay tanrısı benim efendim! [bu ne demek mi oluyor, Ay tanrısı, efendim] bir işaret verdiysen, eğer ki benim için kötülük buyurduysan gör ki, böylece ben [ve]kil getirdim kendi yerime. Artık al bunu [beni serbest bırak!] harpa'nın tepesine canlı bir boğa getirtilir onu harpa- tepesinde kurban ederler. Kral harpa-tepesine çıkar ve şöyle konuşur:..." Kümmel 1967: 9.

${ }^{8}$ Hitit dini hayatında damlar ve kullanımı için bk. Arıkan 2003.

${ }^{9}$ Demanuelli, bu dağ çiftinin Namni ve Hazzi Dağlarınn olmadığını ve bunların Tapala ve Piškurunuwa Dağları olduğunu düşünmektedir. Demanuelli 2015: 625.

${ }^{10}$ Tapala Dağı'nın lokalizasyonu konusunda iki önemli görüş bulunmaktadır. Bu görüşlerden ilki AN.TAH.ŠUM ${ }^{5 ̌ A R}$ bayramındaki bilgilerden dolayı Tapala Dağı'nın Hattuša'ya yakın bir yerlerde olduğudur. Schachner 2014: 25; Sir Gavaz, 2012: 188. İkinci görüş ise Tapala Dağı'nın Hattuša'dan uzakta yer aldığıdır. Lombardi 1997: 97- 100. Demanuelli ise Tapala kelimesinin MÖ II. binyılda demir anlamına geldiğini belirterek, Aladağ'da bulunan Demirkazıktepe'nin Tapala Dağı olabileceğini önermektedir. Demanuelli 2015: 63 - 65, 357.

${ }^{11}$ Piškurunuwa Dağı' nın Hattuša' ya yakın bir yerde bulunduğu düşünülmektedir. Sir Gavaz 2012: 175 - 177.

12 KUB XX 85 I 1-6: “Kral illkbahar'da Tapala Dağına gidince çadırlar önceden kurulur, kral Tapala Dağına gelince çadıra girer." Lombardi 1997: 98 dipnot 53.

13 AN.TAH.ŠUMŠAR bayramının 28. Gününde Tapala dağ1 kral tarafından kutlanmaktadır. Güterbock 1960: 87; Ayrıca Karahna kenti bayramında Tapala Dağı için sunakta bir erkek keçi kurban edilmektedir. McMahon 1991: 60. Ayrıca Tapala Dağının bir İlkbahar bayramına sahip olduğunu da belirtmemiz gerekmektedir.

${ }^{14}$ KBo XXX 69 Ay III 22-23: “Kraliçe oturur, kral ayakta durarak Tapala Dağı ve Tapala Dă̆ı (tanrısı) için içer..."Sir Gavaz 2012: 189.

15 AN.TAH.ŠUMŠAr bayramının 32. gününde "ertesi gün sabah (insanlar) atıştırmak için (aşçların) evine çă̆ı̆ıllırlar. Sonra kral ve kraliçe Inara'nın tapınağına giderler. Ve onlar yolu Piškurunuwa Dağını dahil ederek? belirlerler." Güterbock 1960: 87. Ayrıca KUB XXII 27 IV 30 - 31: Majeste Piškurunuwa Dağına gidince, o günde ABUBITUM'ların evinden bir keçi(yi) (kurban olarak) verirler." Sir Gavaz 2012: 176.

${ }^{16}$ IBoT I.1 IV 9 - 15: "Üç bey waršuli içer. Beklerlerken kral Piškurunuwa Dağı ve Fırtına Tanrısı için bir kez içer." Kloekhorst 2008: 976.
} 
Piškurunuwa Dağı kuzey kültürünü, Tapala Dağı ise güney kültürünü temsil etmiştir. Demanuelli de Lombardi'nin önerisini kabul ederek, Yazılıkaya B Odası IV. Tuthalia kabartmalarındaki dağ tanrılarının Piškurunuwa ve Tapala Dağları olduklarını belirtmiştir (Demanuelli 2015, 625).

Hitit yazılı belgelerinde, belirttiğimiz bu dağlar haricinde çok sayıda dağlardan bahsedilmektedir. Bu dağların büyük çoğunluğu hakkında sadece isimlerini bilebilmekteyiz. Onların lokalizasyonu ve dini önemlerini ortaya koyacak nitelikte yazılı belgeler henüz bulunamamıştır.

\section{Bazı Hitit Kentleri ve Kutsal Dağları}

Hititler yazılı belgelerinde kentlerini belirtmek için "URU" determinitifini kullanmışlardır. Ancak bu deteriminitif çok ayırt edici bir sembol olmamıştır. Çünkü Hititlerin kentlerin veya yaşam alanlarının boyutlarına bakmaksızın hepsi için bu işareti kullandıkları belirtilmiştir (Mielke 2014: 136).

Hititlerin yazılı belgelerinde, onların yerleşim politikaları hakkında detaylı bilgiler veren pasajlar yer almamaktadır. Bazı metinlerde ise yerleşim politikaları ile ilişkili ip ucu olabilecek bilgiler vardır (Mielke 2017: 13). Ancak bu metinler de genellikle yerleşim yerlerinin savunma yapıları ile ilgili olmuşlardır.

Hitit kentleri incelendiği zaman, kentlerde bir standartlaşmanın olmadığını görebilmekteyiz. Bunun sebebi ise bazı kentlerin, eskiden var olan kentlerin üzerine kurulduğu yani bir geçmişlerinin olmasıdır (Mielke 2011: 184; Mielke 2017: 21). Bu duruma en iyi örneklerden birisi Alacahöyük yerleşmesi gösterilebilir. Alacahöyük, Hitit döneminde olduğu gibi Hititlerden önce de önemli bir yerleşme olmuştur.

Hititler yerleşim yerlerini kurarlarken coğrafyaya ve özellikle de bölgenin topoğrafyasına göre hareket etmişlerdir. Bu durum özellikle Hattuša (Boğazkale), Šapinuwa (Ortaköy) ve Sarissa'da (Kuşaklı höyük) görülebilmektedir. Hititler bu kentlerde sadece yaşamamışlar aynı zamanda bölgenin topoğrafyasını kendi ihtiyaçları doğrultusunda kullanmışlardır (Schachner 2014: 13). Yani Hititler çevreyi incelerek yaşam alanlarını, siyasi ve dini yapılarını oluşturmuşlardır. Özellikle bazı kutsal mekanların kent surlarının dışında, topoğrafyanın uygun olduğu yerlerde kurulduğunu düşünmekteyiz.

Kent surlarının dışarısında kalan kutsal mekanlar su kaynakları, açık hava tapınakları, huwaši taşları, kutsal kayalar ve kutsal dağlardan oluşmaktadır (Zimmer - Vorhaus 2011: 196). Hitit yazılı belgelerinde, kentlerin dişında kalan bu açık hava kutsal mekanlarının nasıl belirlendiği konusunda açıklayıcı bilgiler bulunmamaktadır (Ökse 2011: 222). Bizim düşüncemize göre kentlerin yakınlarında bulunan kutsal dağlar, birkaç saatlik yürüme mesafesinde yer almaktadır. Biz bu yayınımımızda, Hitit yönetici veya din adamlarının, kentlerinin kutsal dağlarını belirlerken, beş kilometreye kadar olan yerleri seçtiklerini önereceğiz ${ }^{17}$.

\section{Boğazkale - Yazılıkaya}

Hattuša kenti, döneminin en önemli ve görkemli kentlerinden birisi olmuştur. Eski Önasya siyasi hayatının belirlenmesinde rol oynamıştır. Kent özellikle IV. Tuthalia döneminde yoğun bir şekilde imar edilmiştir. Hattuša' da yapılan arkeolojik kazılarda kentin

\footnotetext{
${ }_{17}$ Schachner'in Hattuša kentini temel alarak, kentten uzaklaşıldıkça mimari izlerinde azalmakta olduğunu iddiası ve yine düşüncesine göre kentten $5 \mathrm{~km}$. sonraki yerler küçük yerleşimlere ait olması önerisi düşüncemizi destekler niteliktedir. Schachner 2014: 23.
} 
imar planının, bölgenin coğrafi şartlarına göre özen gösterilerek hazırlandığı görülmüştür (Schachner 2017: 34).

Hattuša kenti ve özellikle konumuz ile ilgili Yazılıkaya Açık Hava Tapınağı hakkında sayısız çalışma bulunmaktadır. Yazılıkaya Açık Hava tapınağı A, B, ve C odaları olmak üzere üç odadan oluşmaktadır. A Odası'nda Hitit panteonunda yer alan birçok tanrının tasviri yer almaktadır. Panteondaki tanrıların bu odada tasvir edilmesinden dolayı araştırmacılar tarafından ritüellerde toplanılan mekan olarak görülmüştür. B Odasında on iki tanrı, kılıç-tanrı kabartması ve IV. Tuthalia'nın koruyucu tanrısı Šarruma ile kabartması yer almaktadır. Ayrıca odada bulunan nişlerden dolayı burasının IV. Tuthalia'nın ölü kültü için yapılan bir mekan olduğu da araştırmacılar tarafından düşünülmektedir. C odasına bir merdiven yardımı ile ulaşılabilmektedir. Bu odanın Hurri kültürü içinde görülen kuş yakma ritüellerinin uygulandı̆̆ı bir mekan olabileceği düşünülmektedir. Ayrıca Yazılıkaya'nın Hattuša kentinin huwaši'si olduğu da düşünülmektedir (Gurney 1977: 40; Ökse, 2011: 229).

Yazılıkaya'nın dağ eteğinde kayalık bir alanda olmasından dolayı Hattuša kentinin kutsal dağı olduğunu düşünmekteyiz. Büyük bir ihtimalle Yazılıkaya, Hitit sanatçıları tarafından kabartmalar yapılmadan önce de kutsal bir dağ olarak görülmüştür.

Hattuša yakınlarında sıklıkla bahsedilen ${ }^{18}$ önemli bir mekan da Tippuwa Dağı'dır. Bu dağın nerede ve hangi dağ olduğu bilinmemektedir. Yazılı metinlere göre araştırmacılar bu dağın lokalizasyonu için bazı önerilerde bulunmuşlardır ${ }^{19}$. Çalışmamızın konusunu lokalizasyonu büyük ölçüde kesinleşmiş mekanlar oluşturacağı için bu dağın lokalizasyon konusu üzerinde detaylı bir şekilde durmayacağız.

Hititler yerleşim yerlerinin yakınlarında bulunan bazı dağları kutsal mekan olarak görmüşlerdir. Bizim düşüncemize göre Yazılıkaya, başkent Hattuša'nın kutsal dağı olarak görev yapmıştır. Hattuša kenti Hitit Krallığı'nın en büyük kenti olmuştur. Bu kentin oldukça geniş bir alana sahip olmasında dolayı Yazılıkaya ile arasında ölçüm yapıldığı zaman farklı sonuçlar çıkabilmektedir (Hrt. 1). Ancak ortalama bir şekilde, Tapınak I ile Yazılıkaya arasındaki mesafe 1.60 km'dir. Sfenksli Kapı (Yerkapı) yakınlarından mesafe ölçüldüğü zaman ise ortalama $2.50 \mathrm{~km}$ 'dir. Bu mesafe insan yürüyüşüne göre ortalama bir saat gibi kısa bir sürede varabileceği bir mesafe olmuştur. Dolayısıyla Yazılıkaya'nın Hititler tarafından kısa bir sürede ulaşıp geri dönebilecekleri kutsal dağı olduğunu söyleyebiliriz.

\section{Alacahöyük - Kalehisar Tepesi}

Arinna kenti Hitit yazılı belgelerinde, özellikle Arinna'nın Güneş Tanrıçası, Mezulla ve Hulla Dağı ile birlikte geçmektedir (Haas 1994: 586). Bu kentin lokalizasyonu ile ilgili birçok çalışma yapılmış (Popko 1994: 29 - 31; Haas 1994: 592; Popko 1995: 72) ve bu kentin günümüzde Alacahöyük olduğu çok sayıda araştırmacı tarafından kabul edilmiştir.

Arinna kenti ile birlikte geçen Hulla Dağı, Alacahöyük'ün kuzeyindeki Kalehisar Tepesi ile lokalize edilmektedir (Gorny 1997: 556; Sir Gavaz 2012: 136; Blasweiler 2017: 1, 2).

\footnotetext{
18 AN.TAH.ŠUMŠAR bayramının ikinci günü: 19-23 “Ertesi gün kral ve kraliçe Hattusa'ya gider. Tippuwa Dă̆ı'nda korumalar ve saray katılımcıları yarışıllar. Sonra kral ve kraliçe tarnu- evinde banyo yapar. Kral Hattusa'ya GIShuluganni ile gider. Halentu evinde büyük meclis toplanır." Güterbock 1960: 85; Michel 2014: 197, 198.; KUB 10.18 numaralı metinde de kralın Tahurpa'dan Tippuwa'ya geldiğinden bahsedilmektedir. Lombardi 1997: 97 dipnot 47; Archi 2015: 17. Nuntarriyašha bayramının 15. Gününde kral Hattuša kentine Tippuwa aracılığı ile gitmektedir. Sir Gavaz 2014: 8.

19 Tippuwa'nın lokalizasyonu konusunda Hattuša kentine en yakın ve en net öneriyi yapan Ünal'dır. O günümüzdeki Ibikçam'da bulunan az orman kalıntılarının Tippuwa olduğunu düşünmektedir. Ünal 1985: 420; Sir Gavaz hem Hattuša hem de Tahurpa'ya yakın bir konumda olduğunu düşünmektedir. Sir Gavaz 2012: 196. Zippalanda'nın yakınlarında olabileceği Lamante 2009: 153 gibi öneriler bulunmaktadır. Yazılı metinlerde geçen bilgilere göre bu dağın Hattuša yakınlarında olduğunu düşünmekteyiz.
}

SEFAD, 2018 (39): 403-424 
Kalehisar Tepesinin eteklerinde kült yapıları ve kült taşı olduğu düşünülen bir taş bulunmaktadır (Popko: 1995: 146). Kalenin zirvesinde ise Demir Çağına ait bir taht vardır. Dağın eteklerindeki kült yapıları ve dağın zirvesindeki tahttan dolayı bu dağın kutsal bir dağ olduğu düşünülebilir.

Hulla Dağını Hitit metinlerinde görebilmekteyiz. Örneğin KBo 39.62 Vs. ii numaralı metinde "[Kral ayrı]lır. [Kral] Hulla Tapınăğı'nın arkasına [gider]. Ankuwa şehrinin evinin kapısında purpura- ekmeği döker" şeklinde geçmektedir. KUB 55.26 numaralı metinde "Mezulla tapınağındaki kült seremonisinden sonra kral Hulla tapınağını ziyaret eder." cümleleri ile ${ }^{20}$ kralın tapınağa yaptığı ziyaretler belirtilmektedir.

Arkeolojik ve yazılı belgelerden öğrenildiği üzere Hulla Dağı (Kalehisar Tepesi), Arinna (Alacahöyük) kentinin kutsal dağı olmuştur. Bu kent ile kutsal dağı arasındaki mesafe yaklaşık olarak 4 km'dir (Hrt. 2). Bu mesafe, düşüncemize uygun olarak bir insanın yaya olarak kısa bir süre içerisinde gidip gelebileceği bir mesafedir.

\section{Kuşaklı Höyük - Karatonus/Kulmaç Dağı}

Lokalizasyonu konusunda farklı önerilerin ${ }^{21}$ de bulunmasına rağmen, özellikle Kuşaklı höyükte bulunan arkeolojik ve yazılı belgeler sayesinde, Kuşaklı höyügün Sarissa kenti olduğu genel olarak kabul edilmektedir (Müller - Karpe 2002: 154). Bu yüzden çalışmamızda Sarissa Kuşaklı höyük eşitliğini kabul etmekteyiz.

Kuşaklı höyüğün bulunduğu alan incelendiği zaman, bazı diğer Hitit kentlerine göre, daha önemsiz bir bölgede kurulduğu belirtilmiştir ${ }^{22}$. Bu kentin kurulmasının sebebinin dini sebepler olabileceğini düşünmekteyiz. Bizim düşüncemize göre, eğer hem yol güzergahı üzerinde hem de bereketli toprakların üzerinde veya yakınlarında bulunmuyorsa kentin bölgede yer alma amacı dini sebepler olabilir.

Kuşaklı höyügün oldukça yakınında Kulmaç (Karatonus) dağı yer almaktadır. Bu dağın Hitit belgelerinde geçen Sarissa Dağı olduğu düşünülmektedir (Müller - Karpe 2015: 83). Bu dağın üst noktalarında, Hitit metinlerinde de yer alan, kutsal Šupitaššu su kaynağ1 ve göleti bulunmaktadır. Yazılı belgelerde bu kutsal göletin yakınlarındaki huwaši taşında dini ritüellerin yapıldığından bahsedilmektedir (Dörfler vd. 2011: 101; Beckman 2013: 157). Kuşaklı höyükte bulunmuş olan KuT 19 numaralı belgede bu konu hakkında bilgi bulunmaktadır. "ilkbahar geldiği zaman, kral festivali kutlamak için Sarissa'ya gider. Kral şehre gelir gelmez, şehrin içerisine girmez fakat yukarı yolu takip ederek Fırtına Tanrısı'nın huwaši'sine gider." (Gernot 2015: 93)

KBo $21.67+$ CTH 591 iii 19 - 27'de Sarissa Dağ 1 koruyucu bir dağ olarak gösterilmektedir: "Hey Sarissa dă̆̆, ayă̆a kalk! Güçlü kralına, kraliçene, (Hatti ülkesinin) bekçilerine beslenmiş sığır ve keçiler geri dönsün. Onları güçlü yapmaya ve korumaya gel! Iyi haberler onları bulsun, güçlü kral ve kraliçe demirden tahtın üzerinde olsunlar! Onlar mutlu olsunlar! 23". Bu metinden Sarissa Dağı'nın kral, kraliçe ülkedeki birçok varlığı koruyan kutsal bir dağ olarak görüldüğünü söyleyebiliriz.

\footnotetext{
${ }^{20}$ Metinler için bk. Popko 2009: 62.; CTH 385.9 numaralı Askeri başarılar için Arinna'nın Güneş Tanrıçası'na yapılan dua metninde Takurga Dağı'da geçmektedir. Singer, 2002: 108. Bu dağın lokalizasyonu yapılamadığı için konumuza dahil etmiyoruz.

${ }^{21}$ Gurney, etkileyici kalıntıların bulunduğu Kuşaklı Höyük'ün Zippalanda kenti olabileceğini belirtmiştir. Gurney 1995: 71.

22 Mielke Kuşaklı höyüğün ne bir ana yol üzerinde ne de vadinin en bereketli yerinde yer almadığını düşünmektedir. Mielke 2017: 20. Ayrıca bu kent kapladığı alan bakımından da ortalama bir Hitit kentini temsil etmektedir. Mielke 2014: 145.

${ }^{23}$ Metin için bk. Beckman 2013: 155.
}

SEFAD, 2018 (39): 403-424 
Sarissa Dağı ile lokalize edilen Kulmaç/Karatonus Dağı'nın Altınyayla mevkiisinde bir stel bulunmuştur. Altınyayla steli olarak da adlandırılan bu stel geyik üzerinde yer alan tanrıya yapılan libasyon sahnesini göstermektedir. Bu stel, bu dağın, Hititler tarafından ritüellerde kullanılmış olabileceği ve kutsal bir dağ olarak düşünüldüğünü de göstermektedir.

Ayrıca Müller - Karpe, dağın kuzeyinde bir su kaynağının olduğunu belirtmiştir. Bu su kaynağından çıkan suların bir kısmı Fırat Nehri'ne karışarak Arap körfezine dökülmekte, suların bir kısmı Kızılırmak ile karışarak Karadeniz'e dökülmektedir. Çıkan suların diğer bir kısmı ise Seyhan Nehri'ne karışarak Akdeniz'e yani üç farklı denize dökülmektedir. Müller - Karpe'ye göre bu durum Hititler için sembolik bir anlam ifade etmiştir. Ayrıca dağın üzerinde yer alan kutsal yapıların yönü ve ekseni şehre doğrudur. Bu özel durumlar (Müller - Karpe 2015: 83 - 85) Kulmaç/Karatonus Dağı'nın Hititler tarafından kutsal bir dağ olarak düşünüldügüünü göstermektedir.

Kuşaklı höyük (Sarissa) ve onu kutsal dağı Kulmaç/Karatonus (Sarissa Dağı) arasında yaklaşık olarak 3 km'lik bir mesafe bulunmaktadır (Hrt. 3). Zaten KuT 19 numaralı belgeden de anlaşıldığı üzere kral, kente girmeden yukarı yol aracılığı ile kutsal dağa ulaşabilmektedir. Höyük ve kutsal dağ arasındaki yaklaşık 3 km'lik mesafe, yerleşim yeri kutsal dağ arasındaki, birkaç saatte ulaşılabilecek mesafe önerimize uymaktadır.

\section{Oymaağaç Höyük - Adatepe}

Oymaağaç Höyük Samsun ili Vezirköprü ilçesinde yer almaktadır. Bu höyükte yapılan arkeolojik çalışmalarda, "Nerik'in Fırtına Tanrısı için bir fedakârlık" 24 yazan çivi yazılı bir tablet bulunmasından dolayı Nerik kentinin günümüzdeki Oymaağaç Höyük ${ }^{25}$ olabileceği belirtilmiştir.

Yazılı metinlerden öğrenildiği üzere Nerik kenti, Fırtına Tanrısı kültü ile ön plana çıkan bir kent olmuştur. Nerik kenti, Hititlerin kontrolünden çıktığı zaman bu kent ile ilgili ritüeller ${ }^{26} \mathrm{Hakmiš} \mathrm{kentinde} \mathrm{yapılmaya} \mathrm{devam} \mathrm{edilmiştir.} \mathrm{Ritüellerin} \mathrm{kesintisiz} \mathrm{uygulanmaya}$ çalışılması, kentin dinsel önemini açık bir şekilde göstermektedir.

Hitit belgelerinde Nerik kenti Haharwa Dağı ile sıkça anılmaktadır. Örneğin KBo 16.81 numaralı metinde "Ner[ik] şehrinin Fırtına Tanrısı getirildiği zaman [...] [Huzzija(?)], Fırtına Tanrısının adamı (ve) Tahpurili Fırtına Tanrısinın ada[mı] Haharwa'ya götürürler." (Haas 1970: 308) Metinden de anlaşıldığı üzere Nerik Kenti'nin Fırtına Tanrısı Haharwa Dağı'na götürülmektedir. Bu bilgiden hareketle Haharwa Dağı'nın Nerik Kenti'nin kutsal dağ olduğunu düşünebiliriz.

Haharwa Dağının lokalizasyonu konusunda Ada Dağ ve Tavşan Dağları üzerinde durulmuştur. Güterbock Haharwa Dağının, Ada Dağ ile lokalize edilmesini düşünmektedir (Güterbock 1961: 94). McQueen ise Tavşan Dağının eteklerinde görülen arkeolojik kalıntılardan dolayı Haharwa Dağını Tavşan Dağlarına lokalize etmektedir (McQueen 1980: 186).

Nerik kentinin geçtiği belgelerde Zaliyanu Dağından da bahsedilmektedir. Kumarbi mitosunun Hitit versiyonunda Zaliyanu Dağı, Nerik kentine yağmur getiren dağ olarak

\footnotetext{
${ }^{24}$ Czichon 2008: 192. Ayrıca tapınak yapısındaki kazılarda Nerik ve Haharwa Dağı hakkında bilgi veren tabletlerin bulunmasından dolayı Forlanini'de Nerik kentinin Oymaağaç'a lokalizasyonunu kabul etmektedir. Forlanini 2010: $119,120$.

${ }_{25}$ Oymaağaç Höyük'ü, Nerik kentinin haricinde, Hitit metinlerinde geçen Zalpa olabileceği de belirtilmiştir. Bilgi 1998: 69.

${ }^{26}$ Nerik kentinde yapılan bazı ritüel metinleri için bk. Haas 1970; Bozgun - Savaş 2017.

SEFAD, 2018 (39): 403-424
} 
görülmektedir: "(Tanrısal) dă̆ Zaliyanu tüm (tanriların) arasında birincidir. Nerik kentine yağmur geldiği/yă̆dığı zaman, görevliler kalın ekmekleri Nerik kentinden getirirler." (Hoffner 1990: 12) Zaliyanu Dağı'nın lokalizasyonu için Haharwa Dağının bir zirvesi ya da başka bir dağ olabileceği belirtilmiştir (Güterbock 1961: 94).

Tavşan Dağları sıradağlardan oluşan bir dağ sistemidir ve Oymaağaç'a neredeyse 20 km'ye yakın bir mesafededir. Bu mesafe de ritüel katılımcıları için bir günlük yola eşittir. Benzer şekilde Güterbock'un önerisi Ada Dağ'da Oymaağaç Höyüğe oldukça uzak bir mesafede yer almaktadır. KBo 16. 81 numaralı metin Fırtına Tanrısının heykelinin Nerik kentine getirilip aynı gün Haharwa Dağı'na götürüldüğünü anlatmaktadır. Bundan dolayı Oymaağaç Höyük ile Tavşan Dağları ile Ada Dağ arasındaki mesafenin çok uzak olduğunu düşünmekteyiz.

Adatepe, Oymaağaç Höyügün güneyinde bulunmaktadır. $\mathrm{Bu}$ tepede yapılan araştırmalarda, tepenin Erken Tunç Çağında kullanıldığı ve bölgede tek başına duran bir tepe olduğu belirtilmiştir (Czichon vd. 2006). Oymaağaç ile Adatepe arasındaki mesafe yaklaşık olarak $4 \mathrm{~km}$. civarında olmuştur (Hrt. 4). Bu mesafe, tanrı heykelinin ritüel sırasında bir merkezden getirilip ritüel katılımcıları ile birlikte Kutsal dağa götürülebilmesi için daha uygun bir mesafedir. Bu bilgilere göre, Oymaağaç Höyüğün kutsal dağı, höyüğün dört kilometre güneyinde yer alan Adatepe olabilir. Bu mesafe de bizim önerimiz olan yerleşim yeri ile yakınındaki kutsal dağ önerimize uymaktadır.

\section{Ortaköy - Ağılönü}

Ortaköy Hititlerin en önemli merkezlerinden birisi olmuştur. Burada yapılan kazı çalışmalarında, çok sayıda çivi yazılı tablet ve dini hayatta kullanılan objeler ele geçirilmiştir. Bu çalışmalar sonucunda, Ortaköy, Hitit metinlerinde yer alan Šapinuwa ile lokalize edilmiştir (Süel 1995: 283).

Šapinuwa ile ilgili Hitit metinlerinin birçoğunda Šakaddunuwa Dağı geçmektedir. Bu metinlerin birçoğu askeri ve siyasi içerikli metinler olmuştur (De Martino 2016: 105). Bu dağ Karadağ'a lokalize edilmiştir (Alp 1977: 649; Alp 1986: 227). Hitit metinlerine göre bu dağ, dini bir merkezden çok oradan askerlerin alındığı veya inşaatlarda kullanılan kerestenin sağlandığı (Süel 1998: 38) bir dağ olmuştur.

Konumuz açısından incelendiği zaman Ortaköy'ün kutsal dağının Ağılönü Tepesi olduğu görülmektedir ${ }^{27}$. Ağılönü, Ortaköy kentinde araştırmaların yapıldığı Tepelerarası mevkiinin en yüksek yeridir. Ağılönü'nde tapınak olduğu düşünülen bir yapı, girişinde bir ocağın bulunduğu taş döşemli bir yol, kurban çukurları ve ritüellerde kullanıldığ düşünülen birçok obje bulunmuştur (Süel - Ayyıldız 2010: 63, 64, 71; Süel 2015: 101 - 106). Bu buluntular, Ağılönü tepesinin Šapinuwa halkı tarafından, ritüellerin gerçekleştirildiği bir mekan olduğunu göstermektedir.

Ortaköy kazılarının yapıldığı merkez ile Ağılönü Tepesinin arasındaki mesafe yaklaşık olarak 1 km’dir (Hrt. 5). Bu mesafe, kutsal dağ ile yerleşim yeri arasındaki birkaç saatlik yol önerimize uygun olmaktadır ${ }^{28}$.

${ }^{27} 2017$ Eylül ayında birlikte gerçekleştirdiğimiz ziyarette, Ortaköy kazı başkanı Prof. Dr. Aygül Süel de benzer düşüncelerini sözlü olarak bize bildirmiştir. Vermiş olduğu bilgilerden ve gösterdiği yakın ilgiden dolayı kendisine teşekkürlerimizi bildiririz.

${ }^{28}$ Ortaköy kentinin kutsal dağının Karadağ olduğunu düşündüğ̈̈müzde de yine düşüncemiz sınırları içerisinde bir mesafe ortaya çıkmaktadır. 


\section{Çadırhöyük - Çaltepe}

Çadırhöyük Yozgat ili Sorgun ilçesi Peyniryemez Köyü'nde bulunmaktadır. Bu höyükte yapılan arkeolojik kazılarda, höyügün, Kalkolitik dönemden Demir Çağı'nın başlarına kadar yerleşim gördüğ̈̈ tespit edilmiştir.

Zippalanda'nın lokalizasyonu konusunda farklı iddialar ${ }^{29}$ olmasına rağmen, bu kentin Çadırhöyük olduğu düşünülmektedir (Gorny 2006: 10.; Paley 2007: 520). Zippalanda ile ilgili metinlerde sık sık Ankuwa kenti geçmektedir. Güz ve bahar ritüellerini anlatan bayram ritüelinde ${ }^{30}$ Ankuwa kentine haberci gönderilmektedir. Ankuwa Alişarhöyük lokalizasyonunu kabul edersek Çadırhöyügün Zippalanda olma ihtimalinin yüksek olduğunu düşünmekteyiz. Çaltepe'de yapılan araştırmalarda ise Çaltepe'nin tapınak yapısına ve kült nişlerine sahip olduğu belirtilmiştir (Gorny 2005: 20, 21).

Hitit metinlerinde özellikle dini ritüellerde Daha Dağı'ndan bahsedilmektedir. CTH 635 numaralı metinde: “Kral Daha Dağı'nın huwaši taşına gider. Kral huwaši taşına selam verir ${ }^{31}$ ". Bu metinden dolayı Daha Dağı'nda ritüellerin gerçekleştirildiğini söyleyebiliriz. Bo 5045 RS. V numaralı metinin 5-8. satırlarında: “Zippalanda'nın Fırtına Tanrısı ve Daha Dağına küçük lir ile şarkı söylerler." (Popko 1994: 205) ifadeleri yer almaktadır. Bu metinden hareketle Daha Dağı'nın kutsal bir dağ olmasının yanında tanrısal bir dağ olarak da görüldüğünü söyleyebiliriz. KUB 9.17 numaralı metindeki “Daha Dă̆ı'na bir kez içer" (McMahon 1991: 221) ifadesi de bu düşünceyi desteklemektedir.

Zippalanda olduğu düşünülen Çadırhöyük ve onun kutsal dağı Çaltepe olduğu düşünülen Daha Dağı arasında yaklaşık olarak $2 \mathrm{~km}$ mesafe bulunmaktadır (Hrt. 6). Bu mesafe yerleşim yeri kutsal dağ arasında birkaç saatlik mesafe olduğu önerimize uymaktadır. Ayrıca düşüncemizi Taracha'nın önerisi olan Kuşsaray Zippalanda; Kaletepe Daha Dağı eşitliğine uygularsak da benzer sonuca ulaşırız. Çünkü Kaletepe, Kuşsaray höyüğün yaklaşık olarak $500 \mathrm{~m}$. batısında yer almaktadır.

\section{Hatıp Höyük ve Hatıp Kayalıkları}

Hatıp Höyük Konya'nın yaklaşık olarak $16 \mathrm{~km}$. güneyinde yer almaktadır. Bu höyükte ve kayalıkta yapılan incelemelerde MÖ II. Binyıldan itibaren Demir Çağını da içeren arkeolojik bulgular tespit edilmiştir (Bahar 1998: 106; Bahar vd. 1996: 44; Bahar 1999: 46). Hatıp höyüğü, yapısından dolayı Schachner'in höyük tipi merkezler sinıflaması içerisinde düşünebiliriz (Schachner 2017: 33, 34).

Kadeş Savaşı öncesinde, Hitit kralı II. Muwatalli tarafından başkent, Hattuša'dan Tarhuntašša' ya taşınmıştır. Tarhuntašša'nın lokalizasyonu konusunda çeşitli yer önerileri yapılmıştır ${ }^{32}$. Tarhuntašša'nın merkezinin, Kurunta kabartmasından dolayı, Hatıp ve çevresi olabileceğini düşünmekteyiz.

Hatıp kayalıklarının batı kısmında 80 m. çapında, 11 adet burca sahip Geç Tunç Çağı kalesi bulunmaktadır. Ayrıca bu kayalıkta Kurunta kabartması (Bahar 1996: 6 - 7), nişler ve üç adet su kaynağı da bulunmaktadır. Su kaynakları bölgenin su ihtiyacının

\footnotetext{
${ }^{29}$ Gurney Zippalanda'nın Kuşaklıhöyük ile lokalize edilmesi gerektiğini belirtmiştir. Gurney 1995: 71.; Popko Zippalanda'nın Alacahöyük olduğunu düşünmektedir. Popko 1994: 29 - 31; Popko 1995: 72.; Taracha ise Zippalanda'nın Kuşsaray olduğunu iddia etmektedir. Taracha 2015: 58.

30 KUB XX 96 Rs. V 5- 8: “Adamlar tanriyı yerine getirirler, adamlar Ankuwa'ya haberci gönderirler. Kral için iyi sözler söylerler." Popko 1994: 195. Ayrıca KUB XIII 214 Rs. 413 - 17: “Sonbahar olduğu zaman kral arabasına binerek Katapa'ya gider. Ancak sabahın erken saatlerinde Ankuwa'ya gider." Popko 1994: 185.

${ }^{31}$ Ritüelin devamında çeşitli ekmek ve hayvan sunuları vardır. Taracha 2015: 58, 59. Beckman da Daha Dağında bulunan huwaši taşında ritüellerin gerçekleştirildiğini düşünmektedir. Beckman 2013: 154.

32 Tarhuntašša'nın lokalizasyonu hakkında yapılan öneriler için bk. Alparslan 2011.; Turgut 2015: 339, 340.
}

SEFAD, 2018 (39): 403-424 
karşılanmasında oldukça önemli olmuştur. Kayalıkta yer alan nişler de bölgede gerçekleştirilen ritüellerde kullanılmış olabilir.

Hititlere bir süre başkentlik yaptığını düşündüğümüz hatıp Höyük, Tarhuntašša'nın merkezi olmuş olabilir. Kurunta kabartmasının yer aldığı Hatıp Kayalıkları da kentin kutsal dağı vazifesini görmüş olabilir. Yerleşim ile kutsal dağ arasındaki mesafe de $1.50 \mathrm{~km}$ 'dir (Hrt. 7). Bu mesafe bizim yerleşim yeri ile onun kutsal dağı arasındaki birkaç saatlik mesafe olduğu düşüncemize uygun düşmektedir. Belki de eleştiriye açık bir öneri olsa da Hititler, Hatıp Kayalıklarını yeni başkentin Yazılıkaya'sı şeklinde görmüş olabilirler.

\section{Maltepe Höyük - Arısama Dağı}

Maltepe Höyük Konya ilinin Emirgazi ilçesinin yaklaşık olarak $2 \mathrm{~km}$. kuzeyinde yer almaktadır. Bu höyükte ve Emirgazi çevresinde MÖ II. Binyıla ait arkeolojik malzemeleri görülebilmekteyiz.

Maltepe Höyüğün ${ }^{33}$ yakınlarında Arısama Dağı vardır. Bu dağın batısına Eskikışla mevkii ismi verilmiş ve Emirgazi sunakları da bu bölgede bulunmuştur. Emirgazi sunakları üzerindeki yazıtta sıkça Šarpa Dă̆ı'ndan bahsedilmektedir. Sunakların Arısama Dağının batı kısmında bulunmasından dolayı Šarpa Dağı, Arısama Dağı ile lokalize edilmektedir (Hawkins 2006: 57, 58; Taracha 2009: 27, 127; Hawkins 2015: 4). Bu dağ için ayrıca Hasan Dağ (Forlanini 1987: 77.; Demanuelli 2015: 351) ve Kötü Dağ (Özcan 2013: 205, 206) teklifleri de

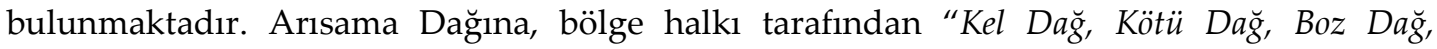
Emirgazi Dağı" gibi isimler verilmektedir ${ }^{34}$. Böylece Kötü Dağ isminin Arısama Dağı'nın isimlerinden birisi olduğu ortaya çıkmaktadır. Bundan dolayı Özcan'ın önerisinin yanlış bir öneri olarak değerlendirilmesi gerektiğini düşünmekteyiz.

Emirgazi yazıtlarının 2-3. satırlarında "ve Šarpa Dağı (üzerine) à.CERVUS ${ }_{3}^{*} 463$ koy ve sonrasında bu steli kendim için diktim" 35 ifadeleri geçmektedir. Yazıtın devamında stele kimsenin zarar vermemesi istenmektedir. Bu bilgiden hareketle bu dağa bir stel dikildiğini ve belki de bu stelin yakınlarında ritüellerin gerçekleştirildiğini düşünebiliriz.

KUB LVII 108 Öy. II 18 -19 numaralı satırlarında "Uda (kentinde) Šahhašaraš, Fırtına Tanrısı, ... [ ] Majeste bu [şeyleri başlattı]: Šarpa (Dağı)'nın öküzü düzenli şekilde sunulacaktır." (Hazenbos 2003: 106) ifadeleri yer almaktadır. Dağa kurban sunulmasından dolayı Šarpa Dağı'nın tanrısal bir dağ olarak da görüldüğünü düşünmekteyiz.

Maltepe Höyük ile Arısama Dağı arasında yaklaşık olarak 1-1,5 km.'lik mesafe bulunmaktadır (Hrt. 8). Bu mesafe bizim yerleşim yeri ile onun kutsal dağı arasındaki birkaç saatlik mesafe olduğu önerimizle de uyuşmaktadır.

\section{SONUÇ}

Eskiçağın birçok toplumunda olduğu gibi Hititler de dağları dini inançlarının etkisiyle kutsal yerler olarak görmüşlerdir. Dağlar, Hititler için, tanrısal varlık, tanrıların yaşadığı yer ve ritüellerin gerçekleştirildiği mekan anlamlarına gelmiştir.

Hititlerin bazı ritüellerini dağlarda gerçekleştirdikleri Hititlere ait ritüel metinlerinden öğrenilmektedir. Bazı ritüellerde, ritüel sırasında yerleşim yerinden dağa gitmişler ve orada ritüellerini gerçekleştirdikten sonra tekrar yerleşim yerlerine geri dönmüşlerdir. Onların bu

\footnotetext{
${ }^{33}$ Metinlerde Šarpa Dağı ile birlikte Uda kentinin çok sık bir şekilde geçmesinden dolayı Uda kenti Maltepe höyük ile lokalize edilmiştir. Özcan 2013: 206.

${ }^{34}$ Gündüz 1980: 60, 202. Yazar Emirgazi sunaklarının Arısama Dağı'nın Eskikışla mevkiinde bulunduğu bilgisini de vermektedir.

35 Yazıt için bk. Hawkins 2006: 55, 56.
} 
yolculuklarını gün içerisinde yapabilmeleri için, kutsal kabul edilen dağların yerleşim yerlerine yakın konumda olmaları gerekmektedir. Bu doğrultuda bizim yerleşim yeri ile kutsal dağ arasındaki mesafe önerimiz $5 \mathrm{~km}$.'dir. Bu mesafe yavaş bir ilerleyişle, neredeyse iki saate denk gelebilecek bir mesafedir. Bu süre de ritüel sırasında rahat bir şekilde, aynı gün içerisinde, gidip geriye dönmeye yetecek bir süredir.

Önerimizi ispatlayabilmek için kullandığımız, Boğazkale, Alacahöyük, Ortaköy, Kuşaklı höyük, Oymaağaç höyük, Çadırhöyük, en önemli Hitit yerleşimleri içerisindedirler. Bu kentler başkente yakın konumda olmuşlardır. Hatıp Höyük ve Maltepe Höyük ise başkente uzak bir konumda yer almışlardır. Boğazkale (Hattuša) ile kutsal dağı Yazılıkaya arasında yaklaşık 1,5 km., Alacahöyük (Arinna) ile Kaletepe (Hulla Dağı) arasında yaklaşık 4 km., Kuşaklı (Sarissa) ile Karatonus/Kulmaç (Sarissa Dağı) arasında yaklaşık 3 km., Oymaağaç (Nerik) ile Adatepe arasında yaklaşık 4 km., Ortaköy (Šapinuwa) ile Ağılönü arasında yaklaşık $1 \mathrm{~km}$., Çadırhöyük (Zippalanda?) ile Çaltepe (Daha Dağı?) arasında yaklaşık 2 km.; Hatıp Höyük ile Hatıp Kale arasında yaklaşık 1,50 km., Maltepe Höyük (Uda?) ile Arısama Dağı (Šarpa) arasında yaklaşık olarak $2 \mathrm{~km}$. mesafe bulunmaktadır. Bu mesafeler önerdiğimiz gibi yerleşim yeri ile onun kutsal dağı arasında $5 \mathrm{~km}$ 'lik mesafe olduğunu gösterebilecek niteliktedir.

Yerleşim yeri ile tahmin ettiğimiz kutsal dağları arasındaki mesafeleri inceleyince, Hititlerin kentlerini planlarken kutsal mekanları da göz önüne aldıkları ortaya çıkmaktadır. Özellikle başkent Hattuša'nın Yazılıkaya ve Hatıp Höyük ile Hatıp Kale arasındaki mesafe dikkat çekicidir. Her iki kent ile kutsal dağı olarak düşündüğümüz mekanlar arasındaki mesafe birbirine çok yakındır. Bu yönüyle Hatıp Höyük Boğazkale'ye yani başkent Hattuša'ya benzemektedir. Hatıp için Tarhuntašša'nın merkezi olarak bir dönem Hititlere başkentlik yaptığı düşünülmektedir. Belki de bu benzerliğin Hitit şehir planlayıcıları tarafından bilinçli bir şekilde yapıldığını da düşünebiliriz.

\section{SUMMARY}

We explained the relation with mount beliefs in the ancient societies in the introduction part of our article. Ancient societies thought mountains as a centre of earth, divine inspiration spaces, sacred places where the Gods lived. Also, we explained Storm God - Bull relation in the introduction.

In the part of Mountain Cult of Hittites, we have examined from where mountain cult was adapted by the Hittites. Also, Hittites viewed mountains as a sacred places where they can perform a ritual.

In the part of some Hittite cities and their sacred mountains, the Hittite settlements were handled. When the Hittites established a city, they took into consideration the topograph of the region. However, there is no explanatory information in the Hittite written sources related with how to choose an open-air sanctuary.

Under the Boğazkale Yazılıkaya topic, we have measured distance between Boğazkale and Yazllıkaya. According to the measurements, there exists approximately $1.60 \mathrm{~km}$ between Temple I and Yazılıkaya. Also, there is $2.50 \mathrm{~km}$ between Yerkapı and Yazılıkaya.

In the part of Alacahöyük Kalehisar hill topic, we examined localization of Arinna to Alacahöyük. When the distance between Alacahöyük and Kalehisar was measured, a $4 \mathrm{~km}$ distance was found between the city and the hill.

SEFAD, 2018 (39): 403-424 
Under the topic of Kuşakl1 mound - Karatonus/Kulmaç mountain, we mentioned the relation with Šarišša mountain from some Hitttie texts. A $3 \mathrm{~km}$ distance between the city and mountain was found.

In the part of Oymaağaç mound Adatepe topic, we examined localization of Nerik, holy city of Hitttites. We think that Adatepe is a sacred mount of Oymaağaç mound. There is a $4 \mathrm{~km}$ distance between Oymaağaç mound and Adatepe.

Šapinuwa is located in Ortaköy. Also Šakaddunuwa mount, mentioned in Hittite texts, is located in Karadağ. But this mount is a place both for taking lumber for buildings and a recruiting district. We believe that Ağılönü hill is a sacred mount of Ortaköy. The sacrifice pits, stone paved way which were used in rituals and ritual objects were found in Ağılönü hill. There is a $1 \mathrm{~km}$ distance between Ortaköy and Ağılönü hill.

Under the topic of Çadır höyük - Çaltepe, we examined localization related with Çadırhöyük. It is generally accepted that Zippalanda is located in Çadırhöyük. Therefore, we can think likewise that Daha mount was Çaltepe. The cultic niches and tempel remains fwere ound on Çaltepe. Daha mountain was mentioned in the Hittte texts related to Zippalanda. The distance between Çadırhöyük and Çaltepe is $2 \mathrm{~km}$.

Under the topic of Hatıp höyük and Hatıp rocky we examined Hatıp höyük and Tarhuntašša which were capitals of the Hittite Kingdom for a short time. The Kurunta relief, cultic niche and springs take part on the Hatıp rocky. There is a 1,50 km distance between Hatıp Höyük and Hatıp Rocky. Maybe Hittites thought Hatıp höyük - Hatıp rocky likewise Boğazkale - Yazılıkaya.

Under the topic of Maltepe höyük - Arısama mount we examined Maltepe Höyük = Uda; Arısama mount = Šarpa mount. The Emirgazi altars were found on the Arssama mount. The distance between Maltepe höyük and Arısama mount is $1-1,50 \mathrm{~km}$.

In conclusion, we suggest that sacred mountains should be close to the city because of the rituals. In this perspective, our suggestion is $5 \mathrm{~km}$ between the city and the sacred mount. We believe that many Hittite cities were planned by taking this into consideration. 


\section{KAYNAKÇA}

Alp, Sedat (1977). "Hitit Kenti Hanhana"nın Yeri". Belleten. XLI. 164: 649-652.

Alp, Sedat (1986). "Maşat Tabletlerinin Eski Anadolu Coğrafyasına Katkıları”. IX. Türk Tarih Kongresi Kongreye Sunulan Bildiriler. 21-25. Eylül 1981. Ankara: Türk Tarih Kurumu Yayınları. 227-233.

Alparslan, M. Doğan (2011) "Anadolu'nun Kayıp Başkenti: Tarhuntassa". Aktüel Arkeoloji. 21: $46-57$.

Archi, Alfonso (2015). "Hittite Religious Landscapes". Sacred Landscapes of Hittites and Luwians Proceedings of the International Conference in Honour of Franca Pecchioli Daddi. eds. Anacleto D'Agostino, Valentina Orsi, Giulia Torri, Firenze: Firenze University Press: 11 -25 .

Arıkan, Yasemin (2003). "Hitit Çivi Yazılı Belgelerinde šuhha- "(Düz) Dam, Çatı" ve Onun Dinsel ve Sosyal Hayattaki Yeri". Archivum Anatolicum (Anadolu Arşivleri). VI, 1: 11 - 57.

Bahar, Hasan - Karauğuz, Güngör vd. (1996). Eskiçă̆ Konya Araştırmaları I. İstanbul: Fs Yayınları.

Bahar, Hasan (1996). "Ein Neues Hethitisches Denkmal in Konya - Hatip". Arkeoloji ve Sanat. 73: $6-7$.

Bahar, Hasan (1998). "Hatıp - Kurunta Anıtı ve Çevresi Yüzey Araştırmaları 1996". XV. Araştırma Sonuçları Toplantısı. II. Ankara: Kültür Bakanlığı Yayınları: 105 - 120.

Bahar, Hasan (1999). Demirçağında Konya ve Çevresi. Konya: Selçuk Üniversitesi Yay.

Baydur, Nezahat (1994). Anadolu'da Kutsal Dağlar Dağ - Tanrılar: Klasik Çă̆. İstanbul: Gaphis Yay.

Beckman, Gary (1996). Hittite Diplomatic Texts. Ed. Harry A. Hoffner Jr.. Atlanta: Society of Biblical Literature Scholar Press.

Beckman, Gary (2013). "Intrinsic and Constructed Sacred Space in Hittite Anatolia". Heaven on Earth Temples, Ritual and Cosmic Symbolism in the Ancient World. ed. Deena Ragavan. Chicago: The Oriental Institute of Chicago. 153 - 173.

Bilgi, Önder (1998). "M. Ö. 2. Binyılda Orta Karadeniz Bölgesi". III. Hititoloji Kongresi Bildirileri. Çorum 16-22 Eylül 1996. Ankara: Uyum Ajans. 61- 75.

Blasweiler, Joost (2017). "The Kalehisar Mountain and the Deities of Arinna, the City of the Sun Goddess". Arnhem. 1: 1- 36.

Bozgun, Şafak - Savaş, Özkan Savaş (2017). "CTH 676: Nerik Kenti “Arınma Ritüeli”. Archivum Anatolicum (Anadolu Arşivleri). 11. 1: 75 - 96.

Brandenstein, Carl - Gecorge (1943). "Hethitische Götter nach Bildbeschreibungen in Keilschrifttexten". MVAeG. 46. 2: 1943.

Bryce, Trevor (2002). Life and Society in the Hittite World. Oxford: Oxford University Press.

Czichon, Raimer M. - Flender, Matthias vd. (2006). "Interdisziplinäre Geländebegehung im Gebiet von Oymaagac-Vezirköprü / Provinz Samsun". Mitteilungen der Deutschen Orient Gesellschaft. 138: 157 - 197.

Czichon, Rainer (2008). “Oymaağaç-Vezirköprü Yüzey Araştırması 2006”. 25. Araştırma Sonuçları Toplantısı. Çorum 28 Mayıs - 1 Haziran 2007. Ankara: Kültür Bakanlığı Yayınları. I. 187-196.

Çevik, Nevzat (2007). "Dağlardaki Tanrılar ve Tanrı Dağlar". Belkıs Dinçol ve Ali Dinçol'a Armağan. ed. Metin Alparslan - Meltem Doğan - Alparslan - Hasan Peker. İstanbul: Ege Yayınları. 175-194.

SEFAD, 2018 (39): 403-424 
Darga, Muhibbe (1985). Hitit Mimarlı̆̆ı I Yapı Sanatı (Arkeolojik ve Filolojik Veriler). İstanbul: İstanbul Üniversitesi Edebiyat Fakültesi Basımevi.

De Martino, Stefano (2016). "Išuwa and Hatti During the Early Empire". Culture and History of the Ancient Near East Audias Fabula Veteres Anatolian Studies in Honor of Jana SouĉkovàSiegelovà. ed. Šàrka Velhartickà, Leiden Boston: Brill. 98 - 110.

Demanuelli, Par Matthieu (2015). La montagne, la vigne et la justice: images et langages des pouvoirs en Cappadoce à l'âge du Fer (début du XIIème - fin du VIIème s. av. J.C.). Entre permanences et mutations. Entre Orient et Occident. Paris: École Pratique des Hautes Études.

Dörfler, Walter - Herking, Christa vd. (2011). "Environment and Economy in Hitttie Anatolia" Insights into Hittite History and Archaeology. eds. Hermnn Genz - Dirk Paul Mielke. Leuven - Paris - Walpole. MA: 98 - 124.

Eliade, Mircea (2004). Babil Simyası ve Kozmolojisi. çev. Mehmet Emin Özcan. İstanbul: Kabalcı Yayınevi.

Eliade, Mircea (2009). Dinler Tarihine Giriş. çev. Lale Arslan. İstanbul: Kabalcı Yayınevi.

Ensert, Hatice Kübra (2006). “RS 17.159 Nolu IV. Tuthaliya'nın Mühür Baskısındaki Küçük Tanrı Figürü II. Murşili midir?". Anatolia. 30: 83-92.

Forlanini, Massimo (1987). "Le Mont Sarpa". Hethitica. 7: 73 - 87.

Forlanini, Massimo (2010). "La Région Autour de Nerik Selon Les Sources Hittites". Studi Micenei ed Egeo- Anatolici. 52: 119-135.

García, Trabazo José Virgilio (2009). "Dıoses-Montaña en las Tradıcıones Indıa, Anatolia". Libvena. 2: $69-88$.

Gernot, Wilhelm (2015). "The Sacred Landscape of Sarissa". Sacred Landscapes of Hittites and Luwians Proceedings of the International Conference in Honour of Franca Pecchioli Daddi. eds. Anacleto D'Agostino, Valentina Orsi, Giulia Torri, Firenze: Firenze University Press. 93-99.

Gorny, Ronald L. (1997). "Zippalanda and Ankuwa: The Geography of Central Anatolia in the Second Millennium B. C. Reviewed Work(s): Zippalanda: Ein Kultzentrum im Hethitischen Kleinasien by Maciej Popko". Journal of the American Oriental Society. 117. 3: $549-557$.

Gorny, Ronald L. (2005). “Project Reports The Alişar Regional Project Excavations on Çadır Höyük". https://cadirhoyuk.files.wordpress.com/2007/10/oi-ch-proofs-06.pdf [25.12.2017].

Gorny, Ronald L. (2006). “2002-2005 Yılları Arasında Çadırhöyük'te Düzenlenen Arkeolojik Kazı Çalışmaları İkinci Bin Yerleşimleri (I)". IDDL Arkeologlar Derneği Dergisi. 30: 8 - 23.

Gurney, Oliver Robert (1977). Some Aspects of Hittite Religion. Oxford: Oxford University Press.

Gurney, Oliver Robert (1995). "The Hittite Names of Kerkenes Dağ and Kuşaklı Höyük". Anatolian Studies. 45: 69 - 71.

Gündüz, İbrahim (1980). Bütün Yönleriyle Karapınar. Konya: Karapınar Belediyesi Yay.

Güterbock, Hans Gustav (1960). “An Outline of the Hittite AN.TAH.ŠUM Festival”. Journal of Near Eastern Studies. XIX. 2: 80 - 89.

Güterbock, Hans Gustav (1961). "The North-Central Area of Hittite Anatolia". Journal of Near Eastern Studies. XX, 2: 85 - 97.

Haas, Volkert (1970). Der Kult von Nerik: Ein Beitrag zur Hethitischen Religionsgeschichte. Roma: Studia Pohl no 4. Päpstliches Bibelinstitut. 
Haas, Volkert (1994). Geschichte Der Hethitischen Religion. Leiden-New York-Koln: Brill.

Hawkins, John David (2006). "Tudhaliya the Hunter". The life and Times of Hattušili III and Tuthaliya IV Proceedings of a Symposium Held in Honour of J. De Roos. Leiden $12-13$ Aralık 2003. Oosten: $49-76$.

Hawkins, John David (2015). "Hittite Monuments and Their Sanctity". Sacred Landscapes of Hittites and Luwians Proceedings of the International Conference in Honour of Franca Pecchioli Daddi. eds. Anacleto D'Agostino, Valentina Orsi, Giulia Torri, Firenze: Firenze University Press: 1-9.

Hazenbos, Joost (2003). The Organization of the Anatolian Local Cults During the Thirteenth Century B. C. Leiden: Brill.

Hoffner, Harry A. Jr. (1990). Hittite Myths. Society of Biblical Literature. ed. Gary M. Beckman. Atlanta Georgia: Scholar Press.

Kloekhorst, Alwin (2008). Etymological Dictionary of the Hittite Inherited Lexicon. Leiden: Brill.

Kümmel, Hans Martin (1967). Ersatzrituale für den hethitischen König. Wiesbaden: O. Harrassowitz.

Lamante, Simona (2009). Il Ruolo di Nerik nel Periodo Imperiale Ittita Il Ruolo di Nerik nel Periodo Imperiale Ittita. Tesi di dottorato. Firenze: Universita di Firenzi.

Lombardi, Alessandra (1997). “Il Culto Delle Montagne All'epoca di Tudhaliya IV: Continuità e Innovazione". Studi Micenei ed Egeo- Anatolici. XXXIX. 1: 85 - 110.

McMahon, Gregory (1991). The Hittite State Cult of the Tutelary Deities. Chicago: The Oriental Instute of the University of Chicago Assyriological Studies.

McQueen J. G. (1980). "Nerik and It's Weather-God". Anatolian Studies. 30, Special Number in Honour of the Seventieth Birthday of Professor Oliver Robert Gurney: 179 - 187.

Michel, Patrick Maxime (2014). Le Culte des Pierres à Emar à L'époque Hittite. Fribourg / Göttingen: Academic Press / Vandenhoeck Ruprecht.

Mielke, Dirk Paul (2011). "Hittite Cities: Looking for a Concept". Insights into Hittite History and Archaeology. eds. Hermnn Genz - Dirk Paul Mielke, Leuven - Paris - Walpole: MA. 153 - 194.

Mielke, Dirk Paul (2014). "Şehirler ve Yerleşim Düzeni. Cities and Settlement Organization". Hititler. Bir Anadolu İmparatorluğu, Hittites. An Anatolian Empire. eds. M. Doğan Alparslan - M. Alparslan. İstanbul: Yapı Kredi Yayınları: 136 - 147.

Mielke, Dirk Paul (2017). "Hittite Settlement Policy". Places and Spaces in Hittite Anatolia I: Hatti and the East. Proceedings of an International Workshop on Hittite Historical Geography. ed. M. Alparslan. İstanbul: Türk Eskiçağ Enstitüsü Bilimleri Yayınları. 13 - 27.

Müller, Andreas - Karpe (2002). "Kuşaklı - Sarissa: A Hittite Town in the "Upper Land". Recent Developments in Hittite Archaeology and History Papers in Memory of Hans Gustav Güterbock. eds. K. Aslıhan Yener and Harry A. Hoffner Jr., Indiana: Eisenbrauns. 145 155.

Müller, Andreas - Karpe (2015). "Planning a Sacred Landscape. Examples from Sarissa and Hattusa". Sacred Landscapes of Hittites and Luwians Proceedings of the International Conference in Honour of Franca Pecchioli Daddi. eds. Anacleto D'Agostino, Valentina Orsi, Giulia Torri, Firenze: Firenze University Press. 83 - 92.

Ökse, Ayşe Tuba (2011). “Open-Air Sanctuaries of the Hittites”. Insights into Hittite History and Archaeology. eds. Hermnn Genz - Dirk Paul Mielke, Leuven - Paris - Walpole: MA. $219-240$.

SEFAD, 2018 (39): 403-424 
Özcan, Ali (2007) “Uda Şehrinin Yeri Hakkında”. Tarih Araştırmaları Dergisi. XXXII, 53: 195 212.

Paley, Samuel M. (2007). "The Excavations at Çadırhöyük". XXVIII. Kazı Sonuçları Toplantısı. Çanakkale 29 Mayıs 2 Haziran 2006. I. Ankara: Kültür ve Turizm Bakanlığı Yayınları. $519-538$.

Popko, Maciej (1994). Zippalanda Ein Kultzentrum im Hethitischen Kleinasien. Heidelberg: Universitatsverlag C. Winter.

Popko, Maciej (1995). Religions of Asia Minor. çev. Iwana Zych. Warsaw: Academic Publications Dialog.

Popko, Maciej (2009). Arinna Eine Heilige Stadt der Hethiter. STBOT 50. Wiesbaden: Harrassowitz Werlag.

Schachner, Andreas (2014). "Hitit Başkenti Hattuşa'nın Yakın Çevresiyle İlişkisi”. 4. Çorum Kazı ve Araştırmalar Sempozyumu Bildiri Kitabı. Çorum 6 Aralık 2013. Çorum: Çorum Valiliği Yayınevi. $11-44$.

Schachner, Andreas (2017). "The Historical Development of the Urban Geography of Hattuša, the Hittite Capital City, and Beyond". Places and Spaces in Hittite Anatolia I: Hatti and the East. Proceedings of an International Workshop on Hittite Historical Geography. ed. M. Alparslan. İstanbul: Türk Eskiçă̆ Enstitüsü Bilimleri Yayınları: 29 - 51.

Schirmer, Wulf (1982). Hitit Mimarlı̆̆ı. Türkçeye çev. Beral Madra, İstanbul: Arkeoloji ve Sanat Yay.

Singer, Itamar (2002). Hittite Prayers. ed. Harry A. Hoffner Jr.. Atlanta Georgia: Society of Biblical Literature.

Sir Gavaz, Özlem (2012). Hitit Krallarının Kült Gezileri, Çorum: Çorum Belediyesi Kültür Yay. Sir Gavaz, Özlem (2014). "A New Contribution to the Hittite Historical Geography: Pertaining to the Location of an Important Cult Centre Katapa". 11. Annual International Conference on History: From Ancient to Modern. Atina 29 Temmuz - Ağustos 2013. Atina: ATINER's Conference Paper Series.

Süel, Aygül (1995). “Ortaköy'ün Hitit Çağındaki Adı”. Belleten. LIX, 225, 276 - 283.

Süel, Aygül (1998). “Ortaköy - Şapinuwa: Bir Hitit Merkezi”. TÜBA-AR. I: 37- 61.

Süel, Aygül (2015). "The Religious Significance and Sacredness of the Hittite Capital City Sapinuwa". Sacred Landscapes of Hittites and Luwians Proceedings of the International Conference in Honour of Franca Pecchioli Daddi. eds. Anacleto D'Agostino, Valentina Orsi, Giulia Torri, Firenze: Firenze University Press. 101 - 111.

Süel, Mustafa - Ayyıldız, Sedef (2010). “Ortaköy/Şapinuwa Ağılönü Mevkiinde Ele Geçen Pencereli Kap". VII. Uluslararası Hititoloji Kongresi Bildirileri. Çorum 25 - 31 Ağustos 2008. I. Çorum: Çorum Valiliği Yayınevi. 63 - 78.

Taracha, Piotr (2009). Religions of Second Millenium Anatolia. Wiesbaden: Harrassowitz Verlag.

Taracha, Piotr (2015). "Looking for Ziplanda, The Hittite Names of Kuşsaray and Kaletepe", Sacred Landscapes of Hittites and Luwians Proceedings of the International Conference in Honour of Franca Pecchioli Daddi. eds. Anacleto D'Agostino, Valentina Orsi, Giulia Torri, Firenze: Firenze University Press. 57 - 66.

Turgut, Murat (2013). Hitit Dini Düşüncesinde Kutsal Mekanlar M. Ö. 1600 - M. Ö. 1200. Yüksek Lisans Tezi. Konya: Selçuk Ü.

Turgut, Murat (2015). “Tarhuntašša'daki Su Kültü Mekanları”. Tarihin Peşinde. (14): 337 354. 
Ünal, Ahmet (1985). "Beiträge zum Fleischverbrauch in der Hethitischen Küche: Philologische Anmerkungen zu einer Untersuchung von A. von den Driesch und J. Boessneck über die Tierknochenreste aus Bogazköy-Hattuša". Orientalia. 54 Nova Series: $419-438$.

Zimmer - Vorhaus, Caroline (2011). "Hittite Temples: Palace of the Gods". Insights into Hittite History and Archaeology. eds. Hermnn Genz - Dirk Paul Mielke, Leuven - Paris Walpole: MA. $195-218$.

\section{EKLER}

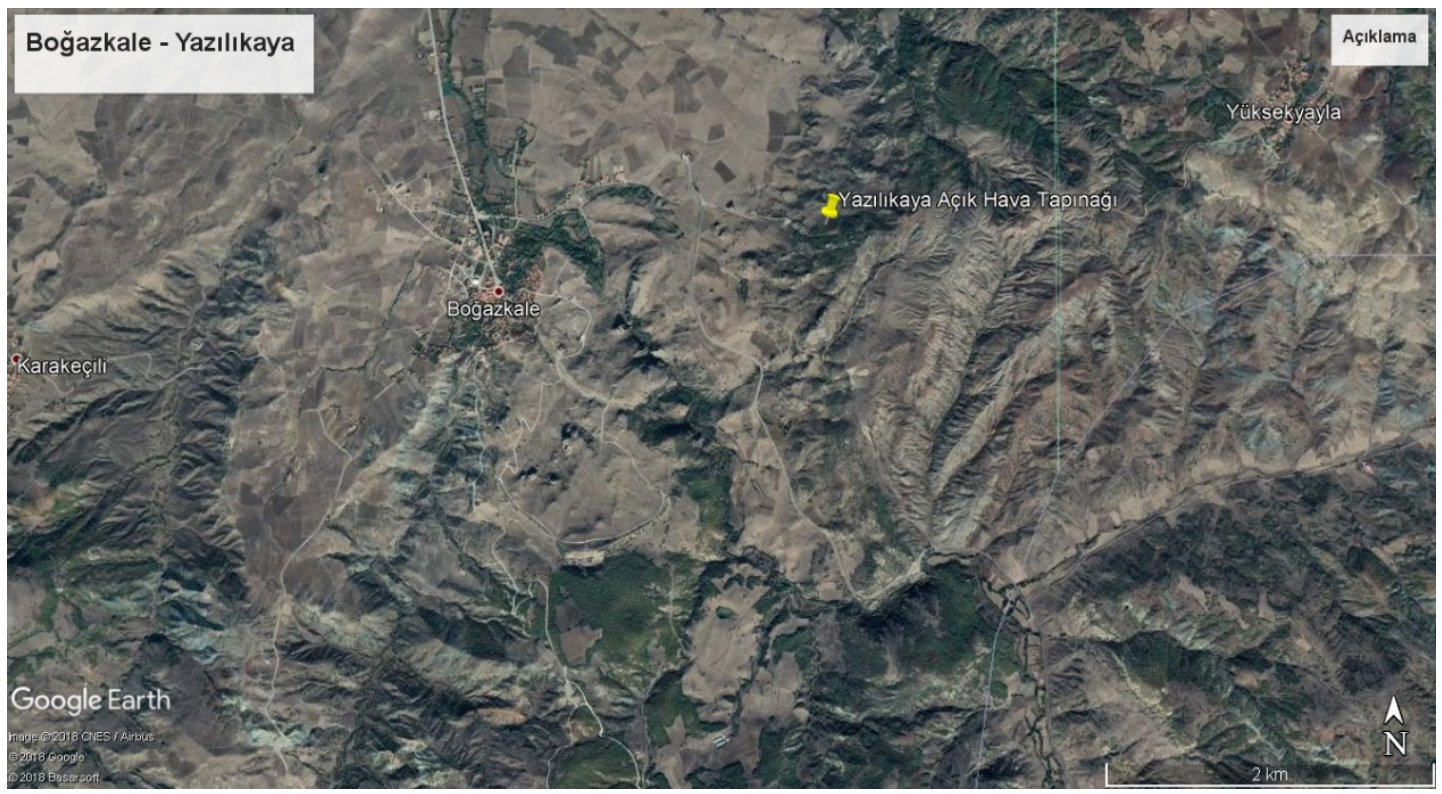

Hrt. 1: Boğazkale - Yazılıkaya

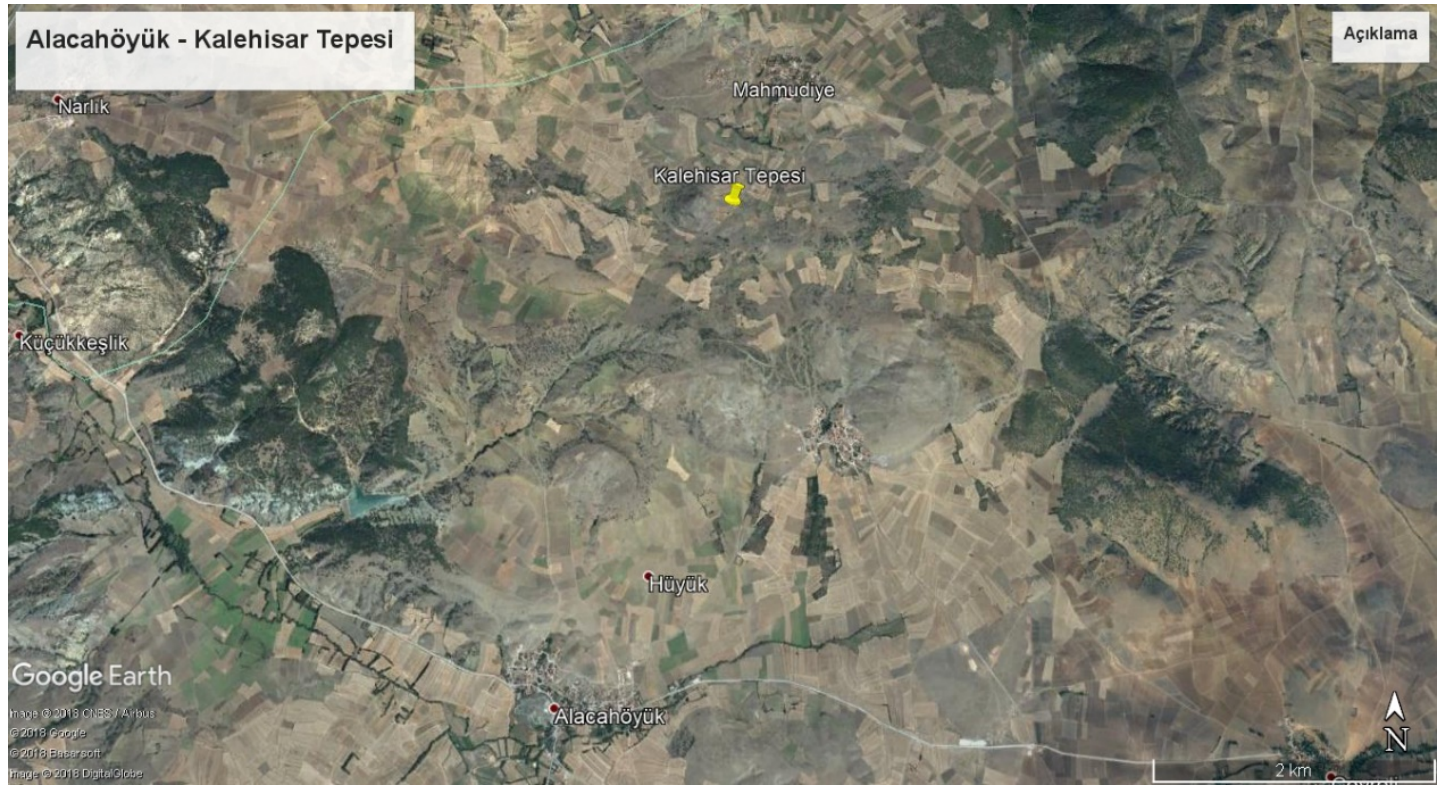

Hrt. 2: Alacahöyük - Kalehisar Tepesi

SEFAD, 2018 (39): 403-424 


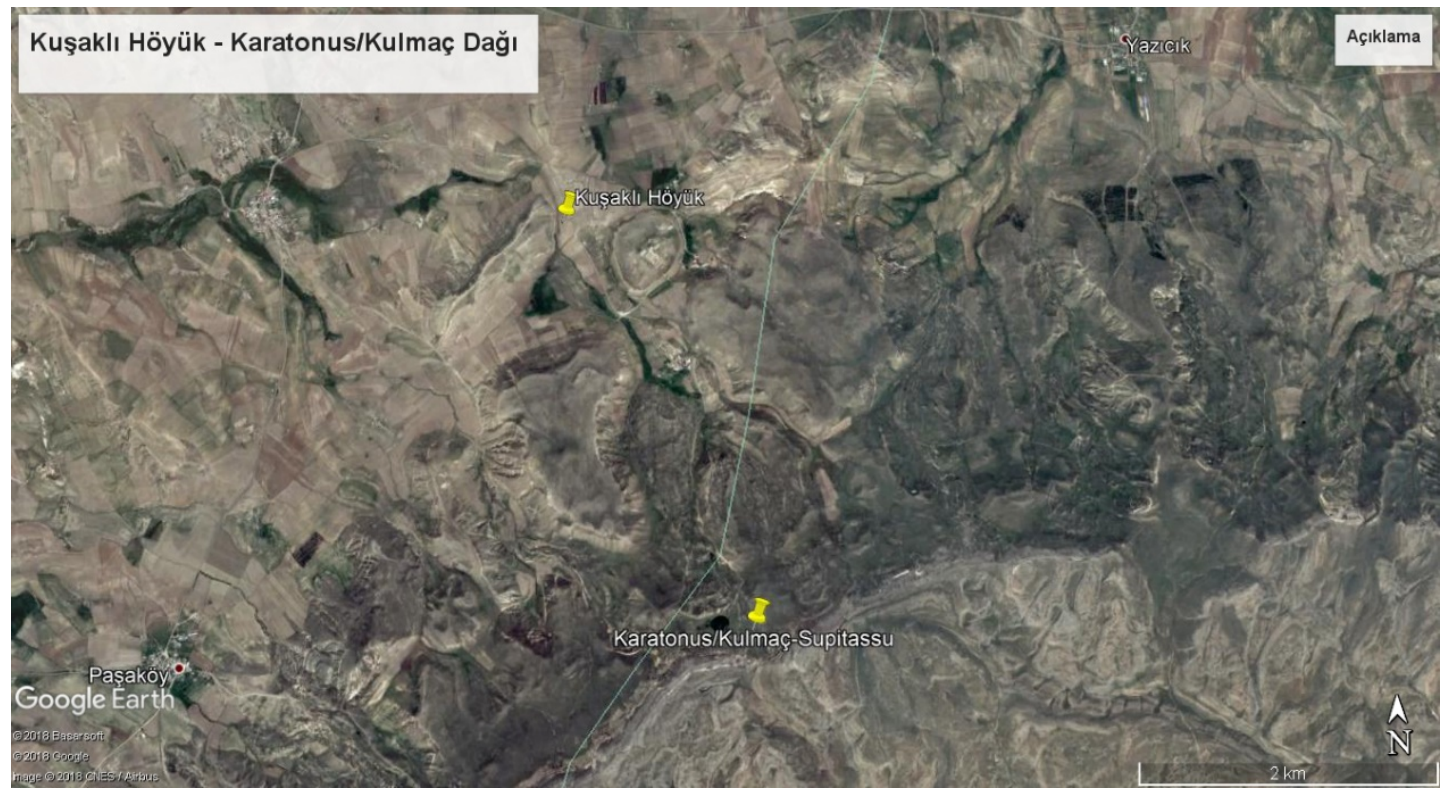

Hrt. 3: Kuşaklı Höyük - Karatonus/Kulmaç Dağı

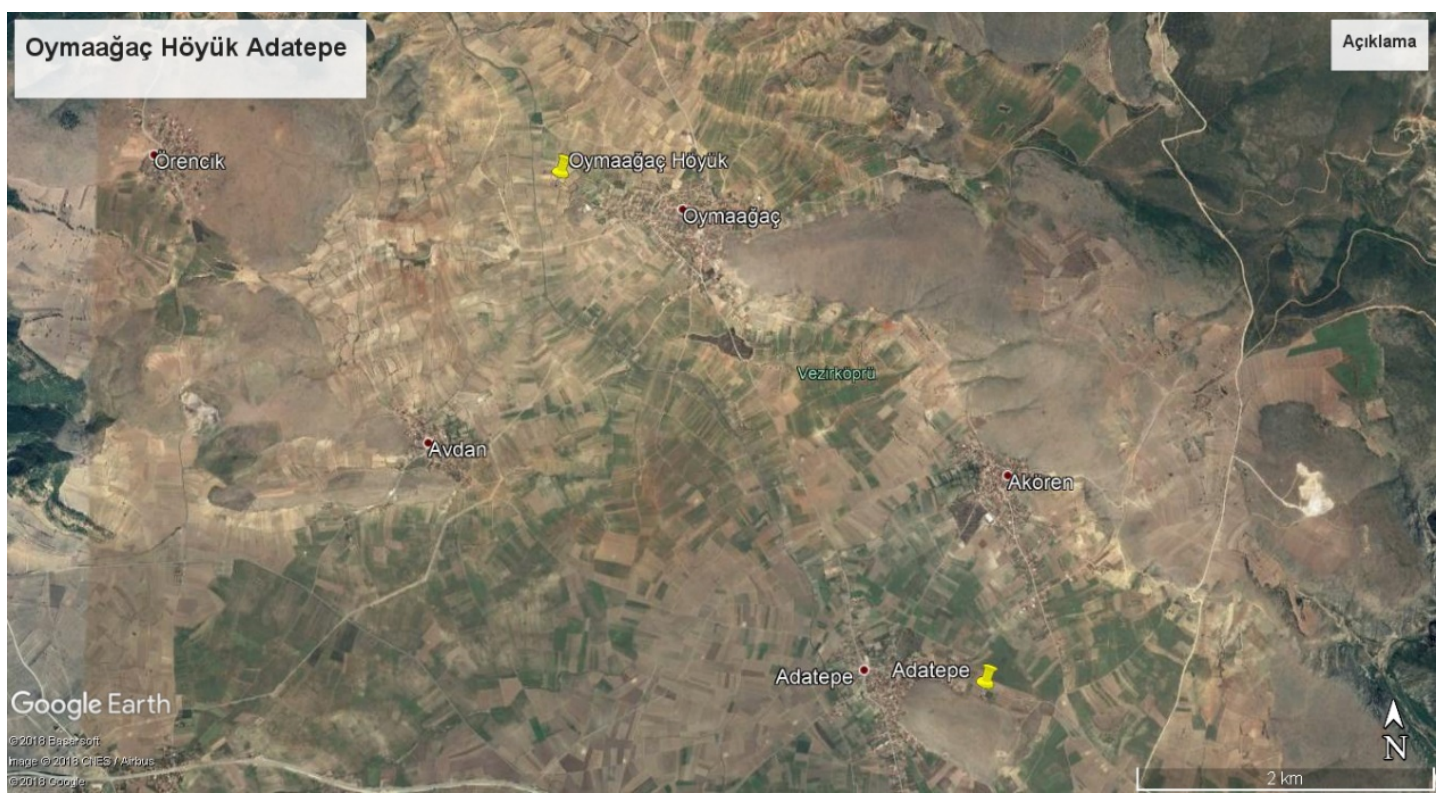

Hrt. 4: Oymaağaç Höyük - Adatepe 


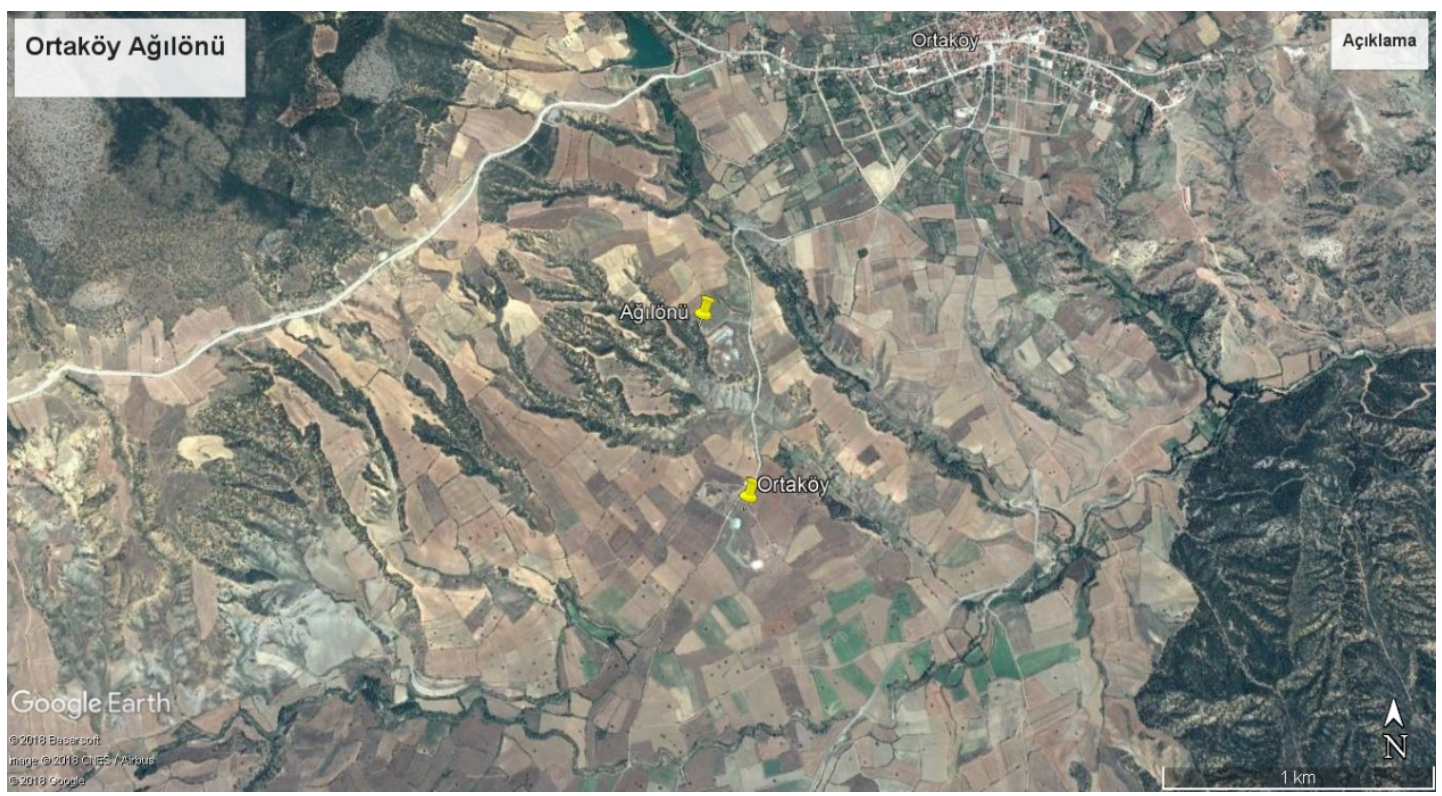

Hrt. 5: Ortaköy - Ağılönü

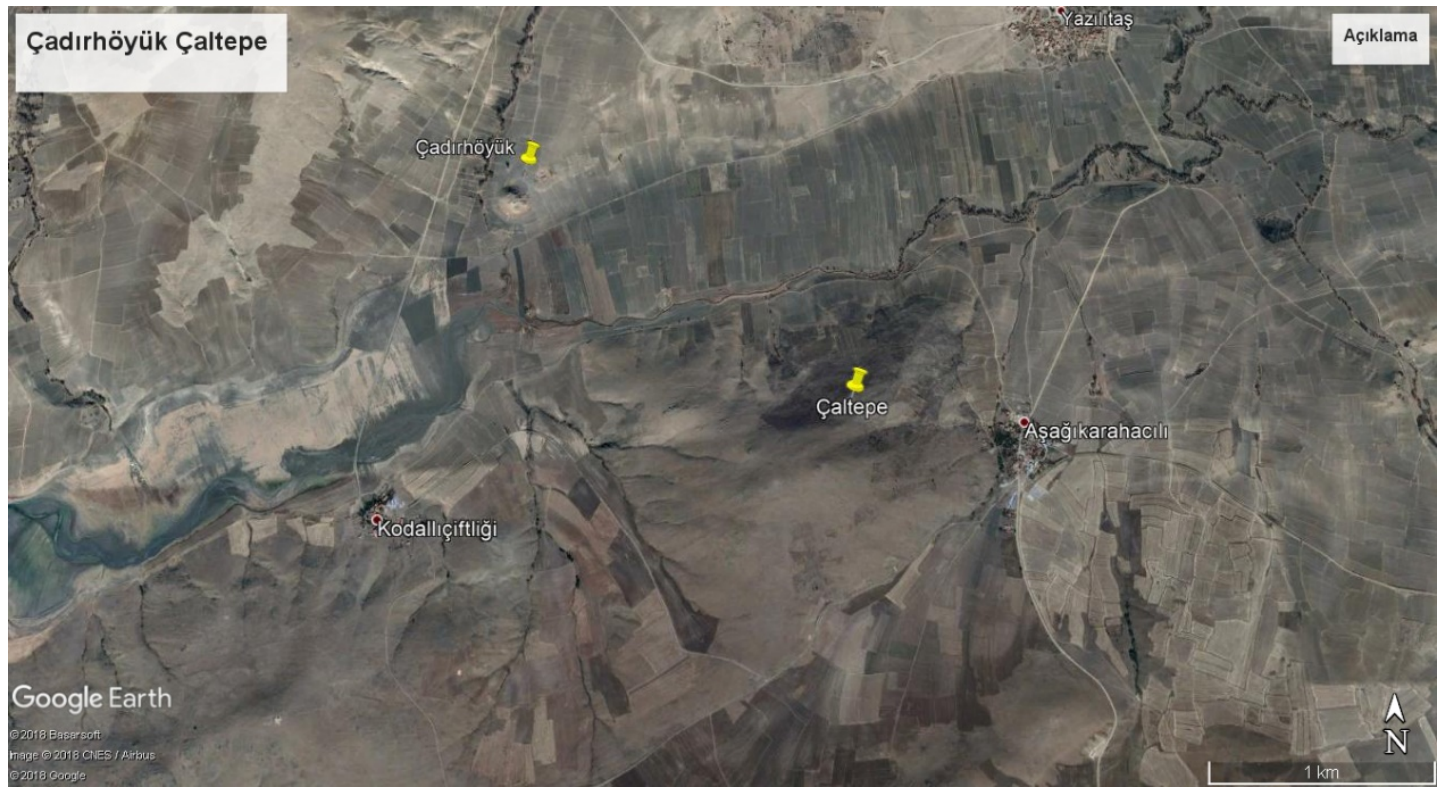

Hrt. 6: Çadıhöyük - Çaltepe 


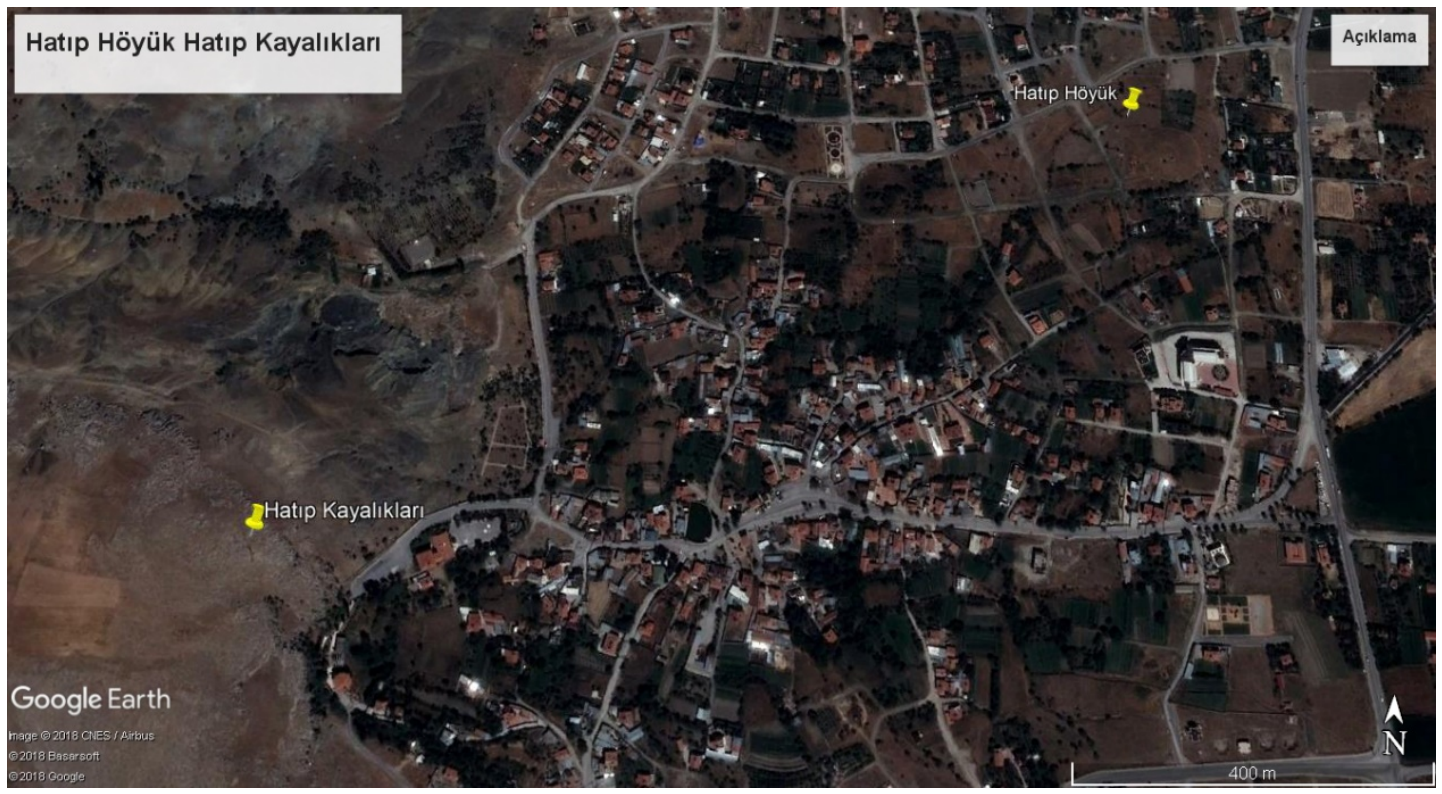

Hrt. 7: Hatıp Höyük - Hatıp Kayalıkları

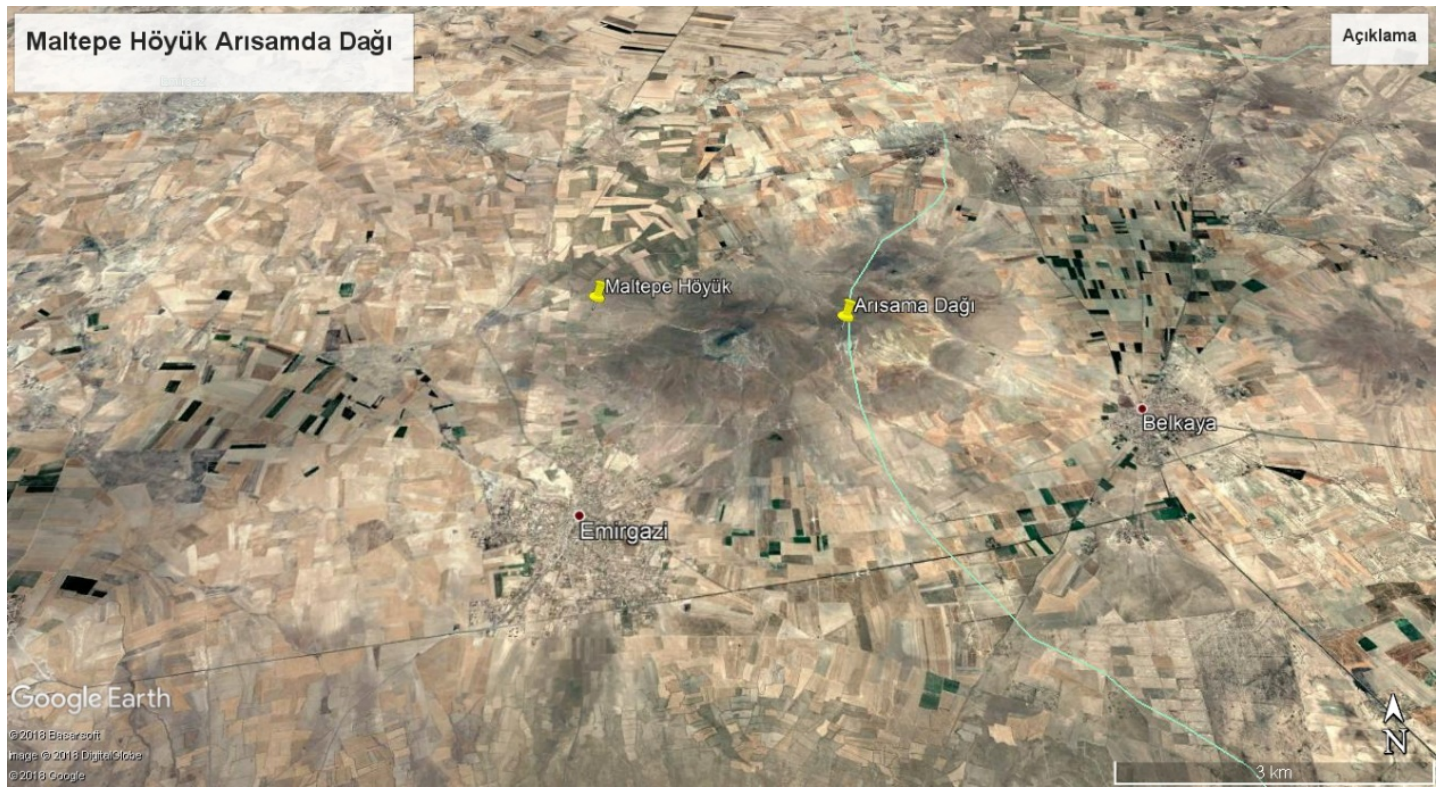

Hrt. 8: Maltepe Höyük - Arısama Dağı 